Takeshi Osada ${ }^{1}$ Kazuki Onji ${ }^{2}$ / David Vera ${ }^{3}$

\title{
Banks Restructuring Sonata: How Capital Injection Triggered Labor Force Rejuvenation in Japanese Banks
}

\author{
${ }^{1}$ Takeshi Osada, Faculty of Economics and Graduate School of Humanities and Social Sciences, Saitama University, Shi- \\ mookubo 255, Sakura-ku, Saitama, 338-8570 Japan, E-mail: takeshiosada@mail.saitama-u.ac.jp \\ ${ }^{2}$ Graduate School of Economics, Osaka University, 1-7 Machikaneyamacho, Toyonaka,Osaka, 560-0043, Japan, E-mail: \\ kazuki.onji@econ.osaka-u.ac.jp \\ ${ }^{3}$ Department of Economics, California State University Fresno, 5245 N. Backer Ave M/S PB20, Fresno, CA 93740-8001, USA, \\ E-mail:dvera@csufresno.edu
}

\begin{abstract}
:
Divergent interests of bank managers and financial regulators potentially compromise the efficacy of bank rescue operations. This study empirically investigates the agency problem encountered in a capital injection program implemented in Japan. We hypothesize that the operations requirement to reduce workforce lead banks to overstate the extent of downsizing by reassigning older workers to bank subsidiaries. We implement a difference-in-differences analysis using a panel of Japanese banks from 1990 to 2010. We also employ propensity score matching to control for sample selection bias. The result shows that injected banks exhibit workforce rejuvenation relative to non-injected banks. Among injected banks, the average employee age falls by approximately 1 year, which is equivalent to a reduction of approximately seventy 65-year-old workers. On an unconsolidated basis, the number of employees in injected banks decreases as a response to the injection. However, on a consolidated basis, which accounts for subsidiary employment, the number of employees does not decrease. Our finding suggests that the Japanese practice of lifetime employment (LTE) survived, albeit in a limited form, among restructured banks.
\end{abstract}

Keywords: recapitalization program, lifetime employment, Japanese banks

JEL classification: G21, J40

DOI: 10.1515/bejeap-2016-0059

\section{Introduction}

The Global Financial Crisis forced governments all over the world to rescue severely affected financial institutions to contain a systemic crisis. Even nonfinancial firms, such as the General Motors, received government assistance. These rescue operations typically entailed government purchases of senior stocks or senior debt of firms in trouble. Similar to any widely held corporations, where ownership and controls differ, managers of government-assisted firms and the regulatory agent need not share the same interests in, for example, executive compensation and employee downsizing. As a result, the agency problem can potentially undermine the effectiveness of a rescue operation. American International Group, which announced extravagant bonus payments to executives after receiving capital injection, is a case in point.

This study aims to provide an empirical documentation on the agency problem relevant for designing a bank rescue operation. We focus on the case of the Japanese capital injection program that commenced in March 1998 in response to a financial crisis. The regulator became an active shareholder with the authority to discipline managers and required banks to downsize workforce as a part of a reconstruction program. Hoshi and Kashyap (2005) first noted that the UFJ Bank met a downsizing target by shuffling workers to its subsidiaries. Onji, Vera, and Corbett (2012) verified the pervasiveness of the personnel shuffling behavior among injected banks, but admitted different scenarios with opposite productivity fallouts. ${ }^{1}$ One possibility is that the injected banks merely relabeled employment contracts and even rehired shuffled employees to parent banks at the end of the capital injection program. The objective of the capital injection program would be compromised under this scenario, since the productivity of the workforce would have remained largely unchanged. Another possibility is that the injected banks shuffled workers nearing retirement age and recruited new workers, once the 
banks were off the program. Under this scenario, the injected banks would have made real adjustments to their workforce, and the productivity should improve. While the extant literature provides evidence on employee shuffling, we do not know if the capital injection program improved the bank workforce productivity without analyzing the dynamics of employment practice. Against this backdrop, this study examines the age composition of banks employees to find whether the Japanese capital injection programs induced injected banks to layoff older employees. ${ }^{2}$ The age composition of banks is also useful in assessing the role of active shareholders in the "death" or "survival" of the lifetime employment (LTE) practice. ${ }^{3}$ A corollary of LTE is that employers shield older workers from negative productivity shocks by reducing job openings for younger workers (Genda 2003). Therefore, the workforce would age if LTE remains intact and banks freeze the recruitment of fresh graduates. Genda and Rebick (2000) observed that changes in employment practices in Japan from the mid-1980s to the late 1990s had been slow, due in part to a lack of shareholder activism. The bank capital injection program is an interesting setting, since the government becomes an active shareholder who sets targets for financial performance and labor costs. Our examination of employee demographics of injected banks would provide insights into how LTE would change in response to a shareholder who demands restructuring.

To investigate the impact of the capital injection program on banks' workforce, we examine the average age of bank employees in conjunction with the number of employees. The information on the workforce size helps us to assess whether a fall in average age is driven by a reduction in older workers or an increase in younger workers. The panel dataset covers financial year (FY) 1990-2010. The number of panel units is 172. We account for mergers by treating banks before and after mergers as separate units.

To identify the impacts of capital injection, we adopt the identification strategy employed by Duchin and Sosyura (2014), who examine the capital injection program in the United States. A simple approach would be to examine how banks with larger capital injection react relative to banks with no injection and lower capital injection. As is well recognized in the literature, however, banks do not receive capital injection randomly. The first step to address the sample selection bias in the literature is to include a number of control variables for bank performance in the regression to absorb the influence of sample selection. This approach would produce a consistent estimate of the policy impact if all the influences of sample selection are captured by the observable characteristics. The second step is to employ propensity score matching (PSM) to assess the robustness of the results from the first step. The idea is to employ a control group consisting of non-injected banks that are similar to injected banks across many dimensions, to account for the selection bias in a more flexible manner than in a linear regression framework. We consider a market-based measure of financial health, and not just measures derived from financial statements, in constructing a control group.

Our results suggest that there is a rejuvenation in the workforce of the banks that were part of the capital injection program. The estimated coefficients roughly translate to a 1-year reduction in average employee age for an average injected bank. To put this estimate in perspective, the magnitude is equivalent to an approximate reduction of seventy 65-year-old workers in a bank with 2,000 workers (i.e. $3.5 \%$ of the workforce). Upon the repayment of injected capital, the average employee age at injected banks falls further by 1.7 years. During this period, a fall in the average employee age is attributable to an increase in younger workers, and the estimated coefficients translate to an additional two-hundred 22-year-old workers. Our examination also offers further support to the hypothesis that injected banks shifted some employees to subsidiaries to achieve restructuring targets. Overall, our study suggests that older workers lost their position at parent banks; however, they were not terminated in full as the banks transferred them to subsidiaries.

This study primarily contributes to a rapidly growing literature examining bank rescue operations. Importantly, our results suggest that the capital injection program in Japan might have facilitated changes in the labor force in injected banks in a way that potentially improves productivity. Our study closely relates to a strand of the literature examining the behavioral responses to capital injection programs. One type of response that has received attention is risk taking by banks. The main objective of capital injection programs is to contain financial system meltdowns. However, policy makers explicitly or implicitly expect the lending business to continue. Such expectations lead banks to meet targets by extending loans to risky lenders or to induce moral hazard by creating the perception that recipient banks are "too-important-to-fail." Some studies examined loan-level data on risk rating and found that the riskiness of loans increased for banks under Temporary Asset Relief Program (Black and Hazelwood 2013; Duchin and Sosyura 2014). In the Japanese program, Giannetti and Simonov (2013) found that large capital injection leads to an increase in the supply of lending to healthy firms, but insufficient injection on the induced banks to lend to "zombie firms." 4 The remainder of this study is organized as follows. Section 2 describes the capital injection programs in Japan. Section 3 describes the data. Section 4 describes the regression analysis. Section 5 presents the results of the regression analysis based on a matched sample of injected and non-injected banks. Finally, Section 6 concludes the study. 


\section{Institutional Background}

\subsection{Capital Injection and the Labor Laws}

The Japanese government administered capital injection programs since 1998 in response to the collapse of several prominent financial institutions in 1997 (Hoshi and Kashyap 2010). The Financial Function Stabilization Act (FFSA) injected a total of 1.8 trillion yen on March 1998 to 21 large banks. Furthermore, the Prompt Recapitalization Act allowed the government to inject 8.6 trillion yen to 32 banks (1999-2002). Injected banks develop a business improvement plan with the Financial Services Agency and lay out targets on financial outcomes (e.g. Tier 1 ratio) as well as restructuring targets such as the number of workers and board members, compensation, overhead costs, and mechanization expenses (Onji, Vera, and Corbett 2012). The target on workforce downsizing tends to be quite aggressive. In 2001, the Ashikaga Bank, for example, targeted a reduction of $26.3 \%$ in its workforce by 2005. If outcomes diverge from the targeted figures, the regulator can invoke an administrative order, which prohibits banks from paying dividend and managerial bonuses. The possibility of punitive measures provides an incentive for the management to meet the personnel reduction target. The regulator monitors the bank's stock in assessing its performance; therefore, the management also faces the pressure to implement an economically meaningful personnel restructuring.

Injected banks, however, need to downsize workforce under a legal system that discourages layoffs. The OECD evaluates Japan as the third most difficult country to layoff workers among 27 countries (OECD 1999). Firms are permitted to layoff workers only after exhausting any alternative means of downsizing, such as recruitment freeze, soliciting early retirement, and permanent transfer to subsidiaries. In addition to the legal system, employment practices in Japan discourage layoffs. Under the LTE and seniority wage practices, workers and firms expect their relationship to last long. Young workers take wages below their marginal products in exchange for a secure employment and future compensation. Thus, a firm that breaks the implicit contract risks damage to its reputation as a reliable employer. Therefore, the difficulties of conducting layoffs create incentives for banks to resort to alternative means to achieve downsizing targets.

The injection program leaves open the definition of "regular workers." The number on reduction may or may not include workers rehired by bank subsidiaries. The lack of a precise definition affords leeway in reshuffling personnel to subsidiaries to meet targets at the parent-bank level, but not on a consolidated basis. For comparison, consider another public support program known as the Law on Special Measures for Industrial Revitalization, enacted for non-financial businesses just 2 years after the FFSA, in 1999. ${ }^{5}$ Firms under this program report targets on the number of employees, breaking it down to temporary transfer (shukkou), permanent transfer (tenseki), as well as the number of newly hired employees.

In theory, how would banks respond to the downsizing requirement? Missing a restructuring target triggers a penalty; thus, we would expect banks to downsize workforce. However, the ambiguity in the reporting requirement under the Japanese capital injection program, in conjunction with the stringent restriction on layoffs in Japan, would lead banks to reshuffle workers to subsidiaries (Onji, Vera, and Corbett 2012). Under the seniority wage practice adopted in the banking industry, older workers receive higher wages. While older workers, who are also more experienced, can be useful at times of distress, banks that need to meet cost targets face pressure to layoff high-wage workers. Moreover, if older workers are on average compensated more than their productivity, as found in the textbook model of seniority wage practice, the profitability target would further add incentives to release older workers. Therefore, we would expect that the restructuring targets would induce banks under the capital injection program to discharge older workers from their core organization.

Would moving older workers to subsidiaries enhance productivity of the parent bank? First, as the real degree of downsizing would not be as great as it appears to be, the bank would not attain the optimal labor force size, if the restructuring target were at the optimal level. If, however, restructuring targets account for the expected friction in labor force adjustment and are above the optimal level, the shuffling behavior would be neutral to productivity. Second, the effects of discharging older workers based on productivity are ambiguous in theory. On one hand, the business restructuring requirements included mechanization of business operations to save on payroll. Further, a shift toward skill-biased technological change (Bresnahan, Brynjolfsson, and Hitt 2002) would increase the demand for IT-literate workers by banks. To the extent that IT-literate workers complement new technologies, we should also expect banks' demand for younger workers relative to older workers to increase, assuming younger workers on average to have more training in IT. In this case, an explicit employee-size target likely helps banks in adjusting the age composition of workforce. On the other hand, given the disincentives under the restructuring program in retaining older workers, banks may retain less number of older workers, who may better cope in time of distress, than it is optimal. Potentially, the shuffling behavior has an important fallout on productivity. 


\subsection{Preliminary Examination}

As a preliminary examination, we plot the time series of average worker age for the three largest regional banks since the late 1970s (Figure 1). Regional banks did not go through as extensive merger process as the larger banks in Japan. Thus, regional banks provide a convenient sample. We also show the case of Sumitomo Trust Bank in the figure, since it did not merge with other banks during the sample period. This sample is not meant to be a representative sample or a group of the most influential banks in Japan. Nonetheless, the four banks have a prominent presence in the economy.

For banks that did not receive capital injection (the Chiba Bank and Shizuoka Bank), the average age increased steadily from around 30 years in the late 1970s to around 40 years by 2010, suggesting that the LTE practice remained generally intact over time. In contrast, the average age at the Bank of Yokohama fell sharply in 2001, 2 years after receiving capital injection, probably reflecting early retirement of older workers. The average age also falls sharply again few years after the repayment. This time, the fall is attributable to increased recruitment of fresh graduates. The average age at the Sumitomo Trust Bank fell since 1999, when the bank received capital, and declined thereafter. While yet tentative, the difference between injected and non-injected banks suggests that the capital injection program caused the retention rate of older employees to fall. We turn to a regression analysis employing all the Japanese banks to find out if this pattern holds for a broader set of banks.

\section{Description of Data}

Our main data source is the Nikkei Economic Electronic Databank Systems' (NEEDS) financial statements data (CD-ROM, version 2011), which contains detailed accounting information and some employee information. We retrieved the fiscal-year-end data of all the Japanese commercial banks that existed between FY1990 and FY2010. The number of banks fell over the sample period, mostly due to mergers: 140 banks in FY1990 to 114 banks in FY2010. Banks that engaged in mergers are treated as new banks. Overall, our dataset constitutes an unbalanced panel covering the period between March 1991 and March 2011.

The main dependent variable is the average employee age. ${ }^{6}$ In the regression analysis, we control for bankspecific characteristics. All variables are from NEEDS and on an unconsolidated basis (i.e. standalone figures for parent banks not including subsidiary outcomes).

To control for the differences among regional labor markets, we used two regional variables from e-Stat (Regional Government Statistics for Japan site): the number of effective job seekers in a region and the average cash wage in the finance and insurance industry. ${ }^{7}$ The average mean of each variable is available for each prefecture and fiscal year for the sample period. Table 1 provides the summary statistics.

\section{Empirical Analysis}

\subsection{Method: Demographic Composition}

Our aim is to analyze the response of bank employees' age composition after both the injections and the repayments of public capital. Once again, the capital injection program required banks that received capital injection to implement personnel downsizing to reduce banks' payroll. If injected banks layoff middle-aged and older employees, who tend to receive higher salaries, the average employee age of these banks would fall. After paying back the injected capital, banks' personnel decisions are no longer constrained by the government monitoring. If in fact banks begin to hire younger workers after repaying the capital, we should also expect a decline in average employee age. Therefore, both capital injection and repayment should affect banks' demographic composition.

To examine this hypothesis, we estimate the following model where the average employee age of a bank is the dependent variable:

$$
\begin{aligned}
A g e_{i, t}= & \sum_{j=0}^{3} \alpha_{j} \operatorname{INJcross}_{i, t-j}+\sum_{j=0}^{3} \beta_{j} \text { PAIDcross }_{i, t-j}+\gamma \operatorname{Age}_{i, t-1}+X_{i, t}^{\prime} \theta+\kappa \\
& +\mu_{i}+\phi_{t}+\epsilon_{i, t}
\end{aligned}
$$


where:

$$
\text { INJcross }_{i, t-j}=\operatorname{INJ}_{i, t-j} \frac{\text { InjCap }_{i}}{\text { Asset }_{i, t}} \quad \text { PAIDcross }_{i, t-j}=\text { PAID }_{i, t-j} \frac{\text { InjCap }_{i}}{\text { Asset }_{i, t}}
$$

$A g e_{i, t}$ is the average employee age of bank $i$ at the end of FY $t$. The lagged dependent variable on the right-hand side captures the sluggishness in making annual adjustments to an existing pool of regular employees hired under indefinite-term contracts.

The main explanatory variables are INJcross ${ }_{i, t-j}$ and PAIDcross ${ }_{i, t-j} \cdot \frac{\text { InjCap }_{i}}{\text { Asset }_{i, t}}$ is the ratio of total amount of capital injection to total asset. This term allows for differences in the intensity of treatment, which should matter if banks with larger government support are under more stringent restructuring plans. This formulation follows Onji, Vera, and Corbett (2012), whose analyses showed the importance of accounting for the intensity of treatment. $I N J_{i, t-j}$ is a dummy for banks that received capital in $t-j$. For banks that received multiple injections, we employ the first injection to define this variable. $P A I D_{i, t-j}$ is also a dummy for banks that paid back all of their injected capital in $t-j$.

In practice, banks gradually repaid injected capital over the years. However, only after all the injected funds are paid do the banks' personnel decisions become independent from government monitoring. PAIDcross $s_{i, t-j}$, therefore, captures the elimination of constraints imposed under capital injection programs.

The effects of capital injection and repayment on bank employees' demographic composition may take time to materialize. To capture lagged effects, we include the explanatory variables at time $t$ and up to 3-year lags. The lag length is chosen to balance a trade-off in modeling. The adjustment is likely to be gradual; therefore, the model should allow for a sufficiently long lagged response. However, a long lag would create an overlap of a period when the injection effects take place with that when the repayment effects take place. The average time for repayment is 7 years and 6 months (Table 2), and the lag of 3 years is sufficiently short to limit overlaps. $X_{i, t}$ is a vector of control variables including bank-specific factors and regional labor market factors. As is well recognized in the literature, banks do not receive capital injection randomly. Therefore, the sample selection process can bias the estimated coefficients. Coefficients on the injection and repayment dummies may capture the average effects of employment reduction in under-performing banks, rather than the direct effects of capital injection programs. To overcome this selection bias, we include the return on assets (ROA) in the regression to control for performance. ${ }^{8}$ In addition, we include the total amount of salaries and allowances, the total number of employees, and the total assets, as other bank-specific controls. The number of effective job seekers and the average cash wage of the finance and insurance industry are included as regional factors. ${ }^{9} \mu_{i}$ and $\phi_{t}$ are fixed effects and $\epsilon_{i, t}$ is an error term. We cluster standard errors at the bank level. $\kappa$ represents the constant term in a regression.

We employ the fixed effects estimator as a benchmark. We prefer this "simpler" estimator to others, such as the generalized method of moments (GMM) estimators, as the dynamic panel bias is not expected to compromise inference in our application. It is well known that the dynamic panel bias affects the coefficient on lagged dependent variables more severely than on covariates (Judson and Owen 1999; Flannery and Hankins 2013). Here, we are interested in the coefficients on the injection and repayment variables, and not that on the lagged dependent variable. While dynamic panel bias can still be a concern, the time-series dimension in our data is of a reasonable size $(T=20)$ and the cross-section dimension is large $(N=173)$. The results in Judson and Owen (1999) suggest that the bias on coefficients and covariates should be small, if any, with this time-series dimension. ${ }^{10}$ To be prudent, however, we conduct a robustness check with a GMM specification.

\subsection{Personnel Shuffling Hypothesis}

In addition to examining the effects on average age, we examine the banks' personnel "shifting behavior" with longer time-series data than that employed in Onji, Vera, and Corbett (2012). The inclusion of a later time period allows us to account for the effects of repayment. We estimate the following eqs (2) and (3):

$$
\begin{aligned}
\text { Employee }_{i, t}^{U N}= & \sum_{j=0}^{3} \alpha_{j} \text { INJcross }_{i, t-j}+\sum_{j=0}^{3} \beta_{j} \text { PAIDcross }_{i, t-j}+\text { Employee }_{i, t-1}^{U N} \\
& +Z_{i, t}^{\prime} \theta+\kappa+\mu_{i}+\phi_{t}+\epsilon_{i, t} \\
\text { Employee }_{i, t}^{\mathrm{CON}}= & \sum_{j=0}^{3} \alpha_{j} \operatorname{INJcross}_{i, t-j}+\sum_{j=0}^{3} \beta_{j} \text { PAIDcross }_{i, t-j}+\text { Employee }_{i, t-1}^{\mathrm{CON}} \\
& +Z_{i, t}^{\prime} \theta+\kappa+\mu_{i}+\phi_{t}+\epsilon_{i, t}
\end{aligned}
$$


Employee $_{i, t}^{U N}$ and Employee ${ }_{i, t}^{C O N}$ are employees on unconsolidated and consolidated basis, respectively, which are both logarithmic values. Not all subsidiaries are consolidated for accounting purposes; generally, a parent company includes majority-owned subsidiaries in a consolidated accounting statement. The number of employees on a consolidated basis thus includes those employed at consolidated subsidiaries, most of which have $50 \%$ or more direct and indirect ownership. If parent banks merely shuffled employees to consolidated subsidiaries, we would expect that the number of employees would fall at the parent-bank level, but not at a consolidated level. With the parent-bank level consolidated data, the present approach would not be able to capture shuffling to unconsolidated subsidiaries. However, in the previous analysis by Onji, Vera, and Corbett (2012), whose data include unconsolidated subsidiaries, most of the responses take place within wholly owned subsidiaries. Thus, the present approach should not lead to a false negative.

One caveat is the limited availability of consolidated data. Consolidated financial reporting was not mandatory until 1999 in Japan, and thus, we do not have data at the consolidated level prior to 1999. In eq. (3), given the shorter time frame, we are only able to estimate the lagged impact of injection for the second and third year. $Z_{i, t}$ a vector of control variables similar to vector $X_{i, t}$ from eq. (1). A difference is that $Z_{i, t}$ includes the average employee age instead of the total number of employees.

\subsection{Results}

Table 3 presents the estimates of eq. (1). The dependent variable is the average employee age. The model in the first column includes all of the control variables, while those for the remainder columns include one control variable at a time.

Looking at the first four rows in Table 3, every coefficient of INJcross is significant and negative, except for the second row. These results suggest that the average age of employees in injected banks gradually fell. How large was the reduction in the average employee age at injected banks? Using the results from the first column in Table 3, we can roughly estimate the extent to rejuvenation as follows; the coefficients on INJcross add to $-52.1\left(=\hat{\alpha}_{0}+\hat{\alpha}_{2}+\hat{\alpha}_{3}\right)$, and as shown in Table 1, the mean value of $\frac{\text { InjCap }_{i}}{\text { Asset }_{i, t}}$ is 0.023 . Therefore, capital injection reduced the average employee age at injected banks by 1.2 years $(-52.1 \times 0.023)$. What does a 1 -year reduction in average age imply about the demographic composition? Consider a bank with 2,000 employees whose average age is 37 years. The average employee age falls by approximately 1 year if sixty-nine 65-year-old workers leave the parent bank.

While the repayment effects are not as strong statistically, we find significant effects after the first and second years of repayments, which are shown in the sixth and seventh rows of Table 3. Almost all of these coefficients are negative and significant, which indicate that the average employee age of injected banks gradually falls 2 years after paying back the injected capital. Using the estimation results of the second column, we can roughly estimate that the average employee age reduces by approximately 1.7 years after paying back the capital. As repayments are typically accompanied by increases in employment, as will be demonstrated below, this reduction in average employee age would have been due to the employment of a younger workforce. If all the new employees consisted of 22-year-old college graduates, this would imply about an additional 204 young workers.

These empirical results confirm that both capital injection and repayment have a negative impact on banks' average employee age. This suggests the possibility that older generations of employees were dismissed or transferred to subsidiaries, several years after injections, and that banks began to hire younger workers 2 years after paying back the capital.

Next, we turn to the effect of injection on the number of employees (Table 4). Injected banks significantly decreased the number of employees 2 years after the first capital injection. However, the number of employees increased significantly immediately after completing the repayment. These results are consistent with the findings from eq. (1). The reduction in the number of employees after capital injection suggests that banks transferred older workers to subsidiaries, while hiring younger workers after repayments.

The result from consolidated financial statements shown in Table 5 contrasts with that from unconsolidated financial statements. We do not detect significant effects of capital injections, even for the coefficient on the 3-year lag, for which the previous model found a strong effect. Even though the reduction of employees occurred on an unconsolidated basis (i.e. a parent bank), no significant reduction occurred on a consolidated basis (i.e. a parent bank and its subsidiaries). This asymmetry suggests an offsetting increase in the number of employees at subsidiaries, and a relocation of employees from a parent to subsidiaries. ${ }^{11}$ The coefficients on repayments are significant and positive for the first and third lags at the $10 \%$ level, indicating that employment increases on the consolidated as well as the unconsolidated bases. ${ }^{12}$ The employment on the consolidated basis, however, seems to take more time to increase than that on the unconsolidated basis, and the effects are not estimated as precisely. The weaker response may be due to several reasons. One possibility is that some of the transferred old workers were re-hired by parent banks. This, however, is not likely to have occurred on a large 
scale given the fall in the average employee age at parent banks documented above. A likely scenario is that the transferees retired, offsetting the increase in young workers at parent banks.

Our empirical results are consistent with previous studies. What is more, we show a new finding that injected banks coped with restructuring programs monitored by adjusting their demographic composition.

\subsection{Robustness Check}

As an alternative to our benchmark estimates, we present the results based on the system GMM estimation. One concern in our original models is the presence of the lagged dependent variable in the right-hand side. In a system GMM, lagged values of the regressors can be used as instrument to correct for a potential bias. To be more specific, relying on the system GMM estimation, we assess the effect of capital injection and repayment on the following: banks' average employee age (model 1), number of employees on an unconsolidated basis (model 2 ), and number of employees on a consolidated basis (model 3). For each of the models, we created a vector of instrumental variables as well as a vector of GMM variables. The variables in the latter are instrumented with their own lags. ${ }^{13}$ Table 6 shows the results from the GMM estimation. Column (1) presents the results on average age; similar to our benchmark results, capital injections tend to decrease the average age of workers. Column (2) shows that, similar to our benchmark results, capital injections decrease the number of workers on an unconsolidated basis, while repayments increase the number of workers. Column (3) shows the results on a consolidated basis; there is no effect of either injection or repayment on the number of workers, which suggests the shifting of employees within subsidiaries (Column 2). Overall, as expected from the studies showing that the dynamic panel bias does not affect coefficient on covariates as much (Flannery and Hankins 2013; Judson and Owen 1999), our results are robust to the dynamic panel bias consideration.

Our empirical strategy is a variant of the difference-in-differences analysis (DID). DID requires that the outcome variables in treatment and control groups follow the same time trend before the treatment (i.e. the common pre-treatment trend assumption). We have checked for pre-treatment trends by employing graphical analyses, placebo tests incorporating a lead variable in the empirical model, and considering Autor (2003) 's "leads-and-lags" model. We find the common pre-treatment trend assumption to be a sensible one and report details in the appendix.

\section{Matching Analysis Using Propensity Score}

The ideal setting to identify the impact of the capital injection is to assign banks randomly to treatment. The injections of capital were clearly not random in practice. In the previous section, we controlled for confounding influences, particularly the effect of poor performance, employing a linear regression specification. This linearity assumption is restrictive if banks' personnel decisions depend on performance in a non-linear way: Banks may adjust personnel only if their performances fall below an implicit level. This section considers a robustness check by constructing a comparable sample of non-injected banks based on propensity score (PS). The key advantage of this matching analysis is that we do not impose the linearity assumption on how the control variables capture the influence of the selection process.

We use PSM to identify non-injected banks that are similar to injected banks across many dimensions. Our goal is to find a more comparable sample of non-injected banks to injected banks, and in application, the PS provides an estimate of the likelihood of a bank receiving a capital injection based on pre-injection observables. We employ a logit model to estimate the PSs. In the matching step, the estimand is the average treatment effect for the treated (ATT) and matching is with replacement.

To estimate the PS, we use the following set of covariates: average worker age, ROA, bank's size, number of workers, and number of job applicants. It is important that we include pre-injection workers' average age in order to meet the selection-on-observables assumption (Dehejia and Wahba 1999). That is, if we do not include pre-injection workers' average age, we may be unable to capture the effect of some other unobservable confounders. ROA is included to ensure that the injected banks are compared to banks with similar financial health in the pre-injection period. Bank size, measured as the natural logarithm of total assets as well as the number of workers, allows us to match injected to non-injected banks in two different alternative dimensions of size. To compare capital-injected banks to non-injected banks with similar labor supply conditions, we use prefecture-level data on the number of job applicants.

We define the pre-injection period to be 1997 and 1998. Although some financial institutions received injection as early as the first quarter of 1998, several banks did not receive capital until the first quarter of 2000. Ideally, we want to estimate the PS for injected and non-injected banks, in a period close to the capital injection. We selected 1997 and 1998 as the pre-injection period because most capital injections occurred after this period, 
and we could expect the capital injection to impact personnel policies with a lag for those that receive capital in early 1998. We use 2004 as the post-injection period. The choice of the post-injection period is based on the average time of the injection years (7 years and 6 months). ${ }^{14}$ Table 7 shows the balance test for the variables included in the matching. The matching significantly improves the proximity of the key variables (average age and number of employees) across the control and treatment group. The matching also improves the comparability of other variables such as ROA, size, and number of job applicants.

Figure 2 shows the kernel density estimates of the age distributions for injected and selected non-injected banks (the matched sample constructed with PS). The left and right panels denote the pre- and post-injection period, respectively. The left panel shows that the age distributions of injected banks (dotted line) and noninjected banks (solid line) are very similar during the pre-injection period. The right panel shows that the distribution for the injected banks is visibly to the left of non-injected banks. ${ }^{15}$ This is consistent with the workforce rejuvenation among the injected banks documented earlier.

\subsection{Results on Matched Sample}

Using the banks' PS to determine a comparable sample of non-injected banks, we estimate the effect of "injection" and "repayment" on the average employee age and number of employees (eqs (2) and (3)) of injected banks using a sample of 40 banks. ${ }^{16}$ Table 8 re-examines the effect of injection on average employee age in the restricted sample (equivalent to Table 3 for full sample). The results are broadly consistent with our previous findings, except that estimates tend to be less precise because of a relatively smaller sample size. The coefficient for INJcross ${ }_{t-3}$ indicates that the average employee age at injected banks fell compared to that of non-injected banks. As the significant coefficient on injection is $-25.0\left(\hat{\alpha}_{3}\right.$ in the first column in Table 8$)$ and the mean value of $\frac{\text { InjCap }_{i}}{\text { Asset }_{i, t}}$ is 0.027 , the average worker at injected banks was 8 months younger than at non-injected banks. The results from the repayment, $P A I D_{i, t-j}$, are now stronger. In all specifications, the average employee age at capital-injected banks falls significantly more than that at non-injected banks. Adding the coefficients on PAID ${ }_{i, t-j}$ for $t-1$ through $t-3$ (-161.5 obtained from the first column in Table 8) and the mean value of $\frac{\text { InjCap }_{i}}{\text { Asset }_{i, t}}$ in this sample (0.027), we estimate that the average employee age falls by 4.36 years at injected banks after the payback.

Table 9 shows the results of the capital injection on the numbers of employees on an unconsolidated basis. Consistent with our findings for the entire sample, the results suggest that capital-injected banks reduced the number of workers during the injection and proceeded to recruit personnel after the repayment. The results on consolidated basis in Table 10 are slightly different from those in Table 9. The coefficient on the second lag of injection is significant, albeit marginally at the $10 \%$ level, in the full specification (Column 1). Unlike previously, however, this coefficient is sensitive to the choice of control variables, as other columns indicate. Repayment had significant positive effects on recruitment. Therefore, the results from the restricted sample are broadly consistent with our previous findings.

\subsection{Sensitivity Analysis}

Since the assignment of banks to treatment and control is not random, there is always a concern that our estimate will be biased. In fact, our estimate of the effect of capital injection based on matching is unbiased if there are no unobserved confounders and if all relevant covariates have been included in the matching model. This is a rather strong assumption and there is always an uneasiness that the matching failed to account for some relevant covariant that was not measured.

One may be concerned that the control variables are insufficient in capturing the selection into treatment. Particularly, the accounting measures of financial health may not be sufficient in producing a comparable sample, if the degrees of financial window dressing differ across banks. If the accounting variable is an insufficient proxy for the actual financial health, the sample selection bias would confound the estimates.

To address this concern, we consider a market-based measure of financial health. If stock investors utilize qualitative information, in addition to accounting information, stock price movements should reflect such additional information not covered in financial statements. To implement this, we construct a different comparison sample by recalculating PS using stock price declines. The change in stock prices is captured for 1997-1998. The results are quantitatively similar to our findings on the original matched sample, suggesting that the accounting measures capture most of the variation in actual performances. ${ }^{17}$ To further examine the key assumption of no unobserved confounder, we present Rosenbaum's sensitivity analysis (Aakvik 2001; Rosenbaum 2002). The aim is to assess if our matching estimator is robust to the possible presence of an unobserved confounder. 
As elaborated by Keele (2010), this analysis relies on the sensitivity parameter Gamma that measures the degree of departure from random assignment of treatment. If assignment to treatment and control is random, Gamma would be one. In other words, Gamma of 1 implies an assumption that an unobserved confounder does not induce any hidden bias. Intuitively, higher values of Gamma allows for larger influences of an unobserved confounder, so by trying out different values of Gamma, we can assess how the conclusion of the analysis varies. ${ }^{18}$ Table 11 presents the Rosenbaum's bounds for the $p$-values for different values of Gamma. The outcome variable is the average age of employees. We select the default range for Gamma. When Gamma equals 1 , the effects of bank capital injections on average age of employees is statistically significant at the 5 percent level. $p$-Values become higher as Gamma increases. Until Gamma of 1.3, the $p$-values are below the 10\% significance level. Gamma of 1.3 implies that, if two banks are identical on matched covariates, one might be 1.3 times as likely to receive treatment because they differ in terms of an unobserved covariates (Keele 2010). Therefore, unless the influence of an unobserved confounder is moderately strong, the estimates remain statistically different from zero. Table 12 presents the Rosenbaum's bounds for the Hodges-Lehmann point estimates (Hollander and Wolfe 1999). The sign of the estimate remains consistently negative across the different values of Gamma. This result is consistent with our main finding that capital injection led to the rejuvenation of the workforce in injected banks. Overall, since small increases in Gamma do not alter the conclusion, this sensitivity analysis suggests that our matching analysis is robust to the possible influence of an unobserved confounder.

\section{Conclusion}

This study empirically examined the demographic composition of banks to find whether the Japanese capital injection program induced injected banks to layoff older employees. The primary contribution of our study is that it provides the first exploration of the relation between a capital injection program and employee demographics. Our results support the following conclusions. First, injected banks tended to layoff older workers at the time of the injection, by relocating them to subsidiaries until retirement. Second, the LTE practice survived in a modified form, rather than being completely abandoned, among injected banks: Workers may not stay until retirement at a parent bank; many of them continue to work at a subsidiary within a corporate group. Despite the popular belief that the Japanese-style employment practice has collapsed, a number of recent studies have documented the resilience of LTE using employee-level data (e.g., Kambayashi and Kato 2010). Our result complements this line of investigation by providing evidence from banks under the capital injection program. Third, if younger workers are more IT literate on average, a rejuvenation of the workforce could have enhanced the productivity in the injected banks. Overall, our results suggest that the capital injection program induced real changes in injected banks' production inputs by rejuvenating their workforce. One of the goals of the capital injection program is to restructure organizations to improve productivity. While direct evidence on improved productivity is yet to be seen, our results indicate that the program did have positive impacts with regard to organizational restructuring.

We interpreted the direction of causality as flowing from the injection program to the labor management and not vice versa. Our prior is that banks would have requested public funding out of financing considerations and regarded requirements on restructuring as being "strings attached." We acknowledge a possibility that the direction of causality, in part, may be reverse. Possibly, bank managers viewed the injection program as a strong inducement for workers to accept layoffs, which is much harder to implement under the Japanese legal system than in Anglo-Saxon countries. The assumption that financial considerations, such as capital falling below the required level, dominates the decision to request capital injection seems a reasonable starting place. However, scrutinizing this assumption for further investigation would be interesting. Finally, our empirical analysis is based on bank-level employee characteristics. Employee-level panel data would provide useful insights by allowing researchers to track relocation of employees within a banking group. 

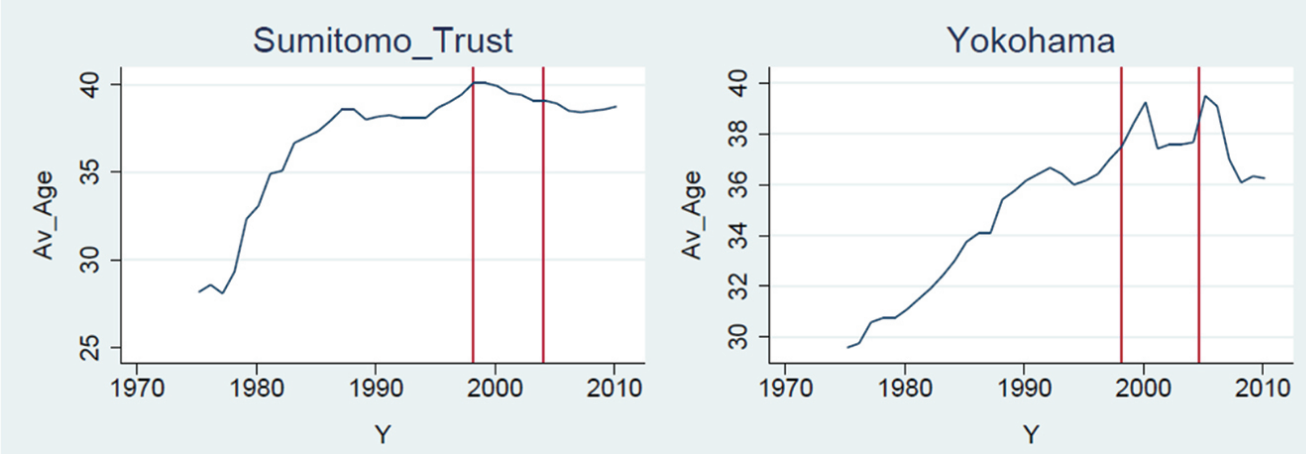

Chiba
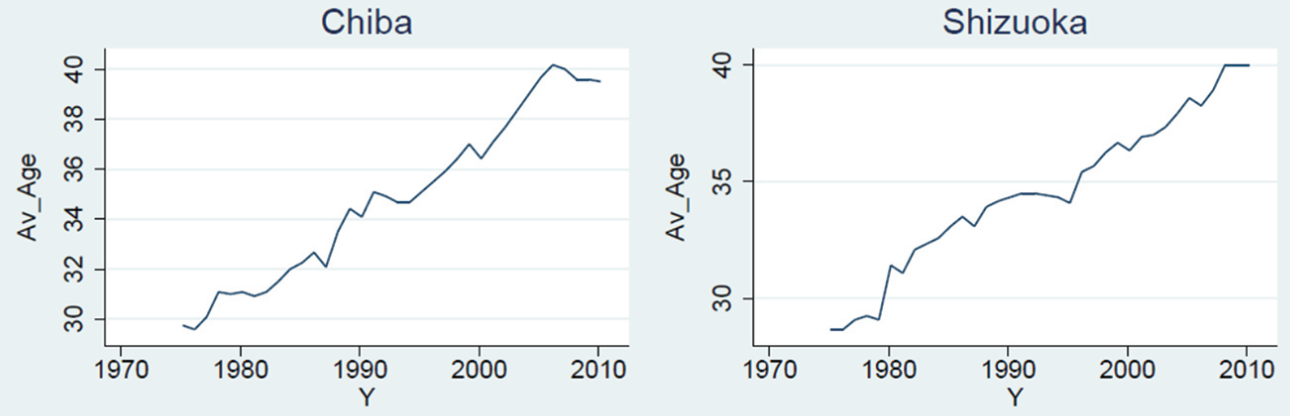

Figure 1: Average employees' age for injected and non-injected banks Time series of average employees' age for two injected banks and two non-injected banks. Sumitomo Trust Bank and Bank of Yokohama are injected banks. Sumitomo Trust Bank received funds in March 1998 and repaid off in January 2004. Bank of Yokohama received in March 1998 and repaid in August 2004. Two vertical lines in each graph show the timing of their injections and repayments. Bank of Yokohama, Chiba Bank, and Shizuoka Bank are three largest regional banks.
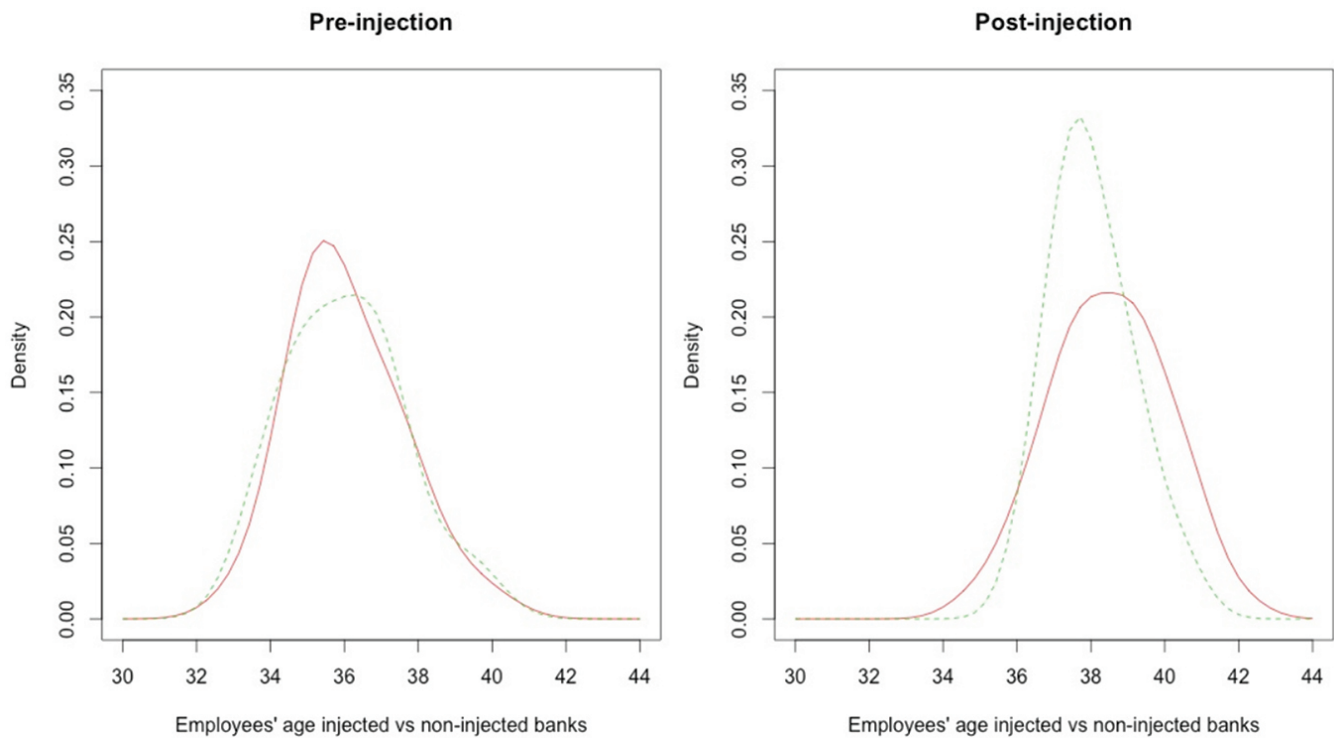

Figure 2: Employees' age-injected versus non-injected banks - Kernel density estimates of the age distributions for injected and selected non-injected banks (the matched sample constructed with PS) are shown. The left and right panel is for the pre- and post-injection period, respectively. Dotted and solid lines show injected banks and non-injected banks, respectively.

Table 1: Summary statistics.

\begin{tabular}{lllllll}
\hline Variable & & Mean & Std. Dev. & Min & Max & Obs \\
\hline Av. Age & level & 37.079 & 2.199 & 30.917 & 43.667 & 2352 \\
$\frac{\text { Injap }}{\text { Asset }_{\text {it }}}$ & ratio & 0.023 & 0.012 & 0.006 & 0.067 & 263
\end{tabular}


Control variables (bank-specific factors)

\begin{tabular}{|c|c|c|c|c|c|c|}
\hline No.employees ${ }^{U N}$ & logarithm & 7.482 & 0.807 & 5.652 & 10.460 & 2352 \\
\hline No.employees $\mathrm{CON}$ & logarithm & 7.520 & 0.853 & 5.872 & 11.004 & 1228 \\
\hline Salary & logarithm & 9.454 & 0.908 & 7.425 & 12.663 & 2352 \\
\hline Total asset & logarithm & 14.641 & 1.208 & 12.303 & 18.852 & 2352 \\
\hline$R O A$ & ratio & 0.045 & 1.049 & -25.333 & 1.603 & 2352 \\
\hline \multicolumn{7}{|c|}{ Control variables (regional labor market factors) } \\
\hline Job applicants & logarithm & 10.759 & 0.897 & 8.586 & 12.517 & 2352 \\
\hline Wage & logarithm & 6.108 & 0.104 & 5.776 & 6.406 & 2352 \\
\hline
\end{tabular}

Notes: Summary statistics for the entire sample: unbalanced panel dataset of 172 banks, covering the period between March 1991 and March 2011. The data on banks' characteristics, Av.Age (Average age), Asset (Total assets), No.employees (The number of Employees), Salary (Total amount of salaries and allowances) and $R O A$, are from the Nikkei Economic Electronic Databank Systems' (NEEDS) financial statements data (CD-ROM, version 2011). The data on amounts of injected money, InjCap ${ }_{i}$, are from Deposit Insurance Corporation of Japan. The data on regional labor market factors, Jobapplicants (the number of effective job seekers) and Wage (Average wage), are from e-Stat (Regional Government Statistics for Japan site).

Table 2: Average time to repayment (years).

\begin{tabular}{|c|c|c|c|}
\hline & $\begin{array}{l}\text { Injection } \\
\text { (yyyymm) }\end{array}$ & $\begin{array}{l}\text { Repayment } \\
\text { (yyyymm) }\end{array}$ & $\begin{array}{l}\text { Time to repayment } \\
\text { (years) }\end{array}$ \\
\hline TOKYO-MITSUBISHI UFJ & 199803 & 200002 & 1.92 \\
\hline MITSUBISHI UFJ TRUST & 199803 & 200101 & 2.83 \\
\hline SUMITOMO TRUST\&BANK & 199803 & 200401 & 5.83 \\
\hline YACHIYO BANK & 200009 & 200603 & 5.50 \\
\hline KYUSHU BANK & 200203 & 200802 & 5.92 \\
\hline BANK OF YOKOHAMA & 199803 & 200408 & 6.42 \\
\hline MIZUHO TRUST \& BANK & 199803 & 200409 & 6.50 \\
\hline MOMIJI BANK & 199909 & 200512 & 6.25 \\
\hline KUMAMOTO FAMILY BANK & 200002 & 200605 & 6.25 \\
\hline IND.BANK OF JAPAN & 199803 & 200508 & 7.42 \\
\hline ASHIKAGA BANK & 199803 & 200602 & 7.92 \\
\hline MITSUI TRUST \& BANK & 199803 & 200503 & 7.00 \\
\hline ASAHI BANK & 199803 & 200510 & 7.58 \\
\hline MIZUHO BANK & 199803 & 200607 & 8.33 \\
\hline MIZUHO CORPORATE BAN & 199803 & 200607 & 8.33 \\
\hline UFJ BANK & 199803 & 200605 & 8.33 \\
\hline TOKAI BANK & 199803 & 200606 & 8.25 \\
\hline UFJ TRUST BANK & 199803 & 200606 & 8.25 \\
\hline SAKURA BANK & 199803 & 200610 & 8.58 \\
\hline CHUO MITSUI TRUST & 199803 & 200607 & 8.33 \\
\hline FUKUOKA CITY BANK & 200201 & 201007 & 8.50 \\
\hline HOKKAIDO BANK & 200003 & 200908 & 9.42 \\
\hline GIFU BANK & 200104 & 201012 & 9.67 \\
\hline BANK OF THE RYUKYUS & 199909 & 201007 & 10.83 \\
\hline HIGASHI NIPPON BANK & 200103 & 201103 & 10.00 \\
\hline HOKURIKU BANK & 199803 & 200907 & 11.33 \\
\hline RESONA BANK & 199803 & $|c|$ & \\
\hline SHINSEI BANK & 199803 & $|c|$ & \\
\hline AOZORA BANK & 199803 & |c|Unpaid & \\
\hline CHIBA KOGYO BANK & 200009 & $|c|$ & \\
\hline KINKI OSAKA BANK & 200104 & $|c|$ & \\
\hline AVERAGE (REPAYERS) & & & $\begin{array}{l}7.52 \\
\text { ( } 7 \text { years and } 6 \text { months) }\end{array}$ \\
\hline
\end{tabular}

Note: This table shows year and month of first injection and complete repayment of each bank, and the average time to repayment of banks which completed repayments.

Table 3: Effects of capital injection and repayment on the average age of employees. 


\begin{tabular}{|c|c|c|c|c|c|c|c|}
\hline Equation & (1) & (1) & (1) & (1) & (1) & (1) & (1) \\
\hline INJcross $_{t-0}$ & $\begin{array}{l}-8.712^{*} \\
(3.978)\end{array}$ & $\begin{array}{l}-8.876^{*} \\
(3.631)\end{array}$ & $\begin{array}{l}-10.123^{* *} \\
(3.732)\end{array}$ & $\begin{array}{l}-9.461^{*} \\
(3.749)\end{array}$ & $\begin{array}{l}-7.886^{*} \\
(3.592)\end{array}$ & $\begin{array}{l}-8.694^{*} \\
(3.510)\end{array}$ & $\begin{array}{l}-8.410^{*} \\
(3.574)\end{array}$ \\
\hline INJCross $_{t-1}$ & $\begin{array}{l}-12.333 \\
(9.349)\end{array}$ & $\begin{array}{l}-3.932 \\
(7.033)\end{array}$ & $\begin{array}{l}-5.174 \\
(6.860)\end{array}$ & $\begin{array}{l}-12.024 \\
(9.452)\end{array}$ & $\begin{array}{l}-3.409 \\
(6.974)\end{array}$ & $\begin{array}{l}-3.484 \\
(6.974)\end{array}$ & $\begin{array}{l}-3.229 \\
(6.947)\end{array}$ \\
\hline INJcross $_{t-2}$ & $\begin{array}{l}-21.771^{*} \\
(10.453)\end{array}$ & $\begin{array}{l}-20.775^{*} \\
(10.115)\end{array}$ & $\begin{array}{l}-21.957^{*} \\
(9.645)\end{array}$ & $\begin{array}{l}-22.615^{*} \\
(10.523)\end{array}$ & $\begin{array}{l}-20.220+ \\
(10.305)\end{array}$ & $\begin{array}{l}-19.751+ \\
(10.358)\end{array}$ & $\begin{array}{l}-20.044+ \\
(10.403)\end{array}$ \\
\hline INJcross $_{t-3}$ & $\begin{array}{l}-21.608^{* *} \\
(6.476)\end{array}$ & $\begin{array}{l}-18.469^{* *} \\
(5.787)\end{array}$ & $\begin{array}{l}-21.025^{* *} \\
(6.000)\end{array}$ & $\begin{array}{l}-21.830^{* *} \\
(6.225)\end{array}$ & $\begin{array}{l}-17.487^{* * *} \\
(5.814)\end{array}$ & $\begin{array}{l}-16.896^{* *} \\
(5.726)\end{array}$ & $\begin{array}{l}-17.561^{* *} \\
(5.824)\end{array}$ \\
\hline PAIDcross $_{t-0}$ & $\begin{array}{l}10.944 \\
(13.282)\end{array}$ & $\begin{array}{l}12.123 \\
(14.587)\end{array}$ & $\begin{array}{l}10.710 \\
(14.452)\end{array}$ & $\begin{array}{l}9.361 \\
(13.320)\end{array}$ & $\begin{array}{l}12.926 \\
(14.801)\end{array}$ & $\begin{array}{l}14.097 \\
(15.009)\end{array}$ & $\begin{array}{l}12.986 \\
(14.792)\end{array}$ \\
\hline PAIDcross $_{t-1}$ & $\begin{array}{l}-21.584+ \\
(11.430)\end{array}$ & $\begin{array}{l}-23.776^{*} \\
(9.920)\end{array}$ & $\begin{array}{l}-24.522^{*} \\
(10.429)\end{array}$ & $\begin{array}{l}-25.090^{*} \\
(11.426)\end{array}$ & $\begin{array}{l}-22.944^{*} \\
(9.577)\end{array}$ & $\begin{array}{l}-20.990^{*} \\
(9.620)\end{array}$ & $\begin{array}{l}-22.815^{*} \\
(9.571)\end{array}$ \\
\hline PAIDcross $_{t-2}$ & $\begin{array}{l}-42.322 \\
(28.454)\end{array}$ & $\begin{array}{l}-48.286+ \\
(26.955)\end{array}$ & $\begin{array}{l}-47.219+ \\
(27.792)\end{array}$ & $\begin{array}{l}-47.457+ \\
(28.531)\end{array}$ & $\begin{array}{l}-47.819+ \\
(26.571)\end{array}$ & $\begin{array}{l}-45.490+ \\
(26.302)\end{array}$ & $\begin{array}{l}-47.839+ \\
(26.493)\end{array}$ \\
\hline PAIDcross $_{t-3}$ & $\begin{array}{l}-21.660 \\
(22.360)\end{array}$ & $\begin{array}{l}-25.427 \\
(21.242)\end{array}$ & $\begin{array}{l}-25.470 \\
(21.792)\end{array}$ & $\begin{array}{l}-24.674 \\
(22.632)\end{array}$ & $\begin{array}{l}-25.218 \\
(20.953)\end{array}$ & $\begin{array}{l}-23.698 \\
(20.454)\end{array}$ & $\begin{array}{l}-25.132 \\
(20.913)\end{array}$ \\
\hline Lag of dep. var. & $\begin{array}{l}0.751^{* *} \\
(0.032)\end{array}$ & $\begin{array}{l}0.778^{* *} \\
(0.031)\end{array}$ & $\begin{array}{l}0.769^{* *} \\
(0.031)\end{array}$ & $\begin{array}{l}0.759^{* *} \\
(0.032)\end{array}$ & $\begin{array}{l}0.782^{* *} \\
(0.031)\end{array}$ & $\begin{array}{l}0.779 * * \\
(0.031)\end{array}$ & $\begin{array}{l}0.782^{* *} \\
(0.031)\end{array}$ \\
\hline Salary & $\begin{array}{l}0.567^{* *} \\
(0.192)\end{array}$ & $\begin{array}{l}-0.163 \\
(0.136)\end{array}$ & & & & & \\
\hline Asset & $\begin{array}{l}-0.261 \\
(0.207)\end{array}$ & & $\begin{array}{l}-0.462^{* *} \\
(0.155)\end{array}$ & & & & \\
\hline Employees ${ }^{U N}$ & $\begin{array}{l}-1.040^{* *} \\
(0.293)\end{array}$ & & & $\begin{array}{l}-0.709^{* *} \\
(0.191)\end{array}$ & & & \\
\hline$R O A$ & $\begin{array}{l}0.011 \\
(0.014)\end{array}$ & & & & $\begin{array}{l}0.006 \\
(0.011)\end{array}$ & & \\
\hline Job applicants & $\begin{array}{l}0.494^{*} \\
(0.212)\end{array}$ & & & & & $\begin{array}{l}0.404+ \\
(0.214)\end{array}$ & \\
\hline Nominal wage & $\begin{array}{l}-0.112 \\
(0.294)\end{array}$ & & & & & & $\begin{array}{l}0.021 \\
(0.296)\end{array}$ \\
\hline Constant & $\begin{array}{l}10.698^{*} \\
(4.550)\end{array}$ & $\begin{array}{l}9.346^{* *} \\
(1.832)\end{array}$ & $\begin{array}{l}14.856^{* *} \\
(2.775)\end{array}$ & $\begin{array}{l}13.878^{* *} \\
(2.095)\end{array}$ & $\begin{array}{l}7.662^{* *} \\
(1.091)\end{array}$ & $\begin{array}{l}3.610 \\
(2.370)\end{array}$ & $\begin{array}{l}7.549^{* *} \\
(2.214)\end{array}$ \\
\hline Observations & 2,352 & 2,357 & 2,359 & 2,354 & 2,359 & 2,359 & 2,359 \\
\hline$R$-squared & 0.897 & 0.894 & 0.895 & 0.896 & 0.894 & 0.895 & 0.894 \\
\hline Number of banks & 172 & 173 & 173 & 172 & 173 & 173 & 173 \\
\hline
\end{tabular}

Note: Estimation results of eq. (1) that shows the effect of injection and repayment of capital on employees' average age. The model in the first column includes all of the control variables while those for the remainder columns include one control variable at a time. Robust standard errors in parentheses are clustered at the bank level.

$* 0<0.01$

$* p<0.05$,

$+p<0.1$

Table 4: Effects of capital injection and repayment on the number of employees - unconsolidated basis.

\begin{tabular}{llllllll}
\hline Equation & $\mathbf{( 2 )}$ & $\mathbf{( 2 )}$ & $\mathbf{( 2 )}$ & $\mathbf{( 2 )}$ & $\mathbf{( 2 )}$ & $\mathbf{( 2 )}$ & $\mathbf{( 2 )}$ \\
\hline INJcross $_{t-0}$ & 0.032 & -0.374 & -0.786 & $-0.753+$ & -0.487 & $-0.982^{*}$ & $-1.021^{*}$ \\
& -0.336 & $(0.327)$ & $(0.641)$ & $(0.382)$ & $(0.403)$ & $(0.470)$ & $(0.473)$ \\
INJ cross $_{t-1}$ & -1.173 & -1.178 & $-2.429+$ & $-1.720+$ & $-2.796^{*}$ & $-2.624^{*}$ & $-2.670^{*}$ \\
& $(0.949)$ & $(0.939)$ & $(1.344)$ & $(0.990)$ & $(1.255)$ & $(1.271)$ & $(1.269)$ \\
INJ cross $_{t-2}$ & $-1.098^{* *}$ & $-0.709^{*}$ & -0.424 & $-1.326^{* *}$ & -0.602 & -0.542 & -0.510 \\
INJcross $_{t-3}$ & $(0.383)$ & $(0.342)$ & $(0.494)$ & $(0.263)$ & $(0.451)$ & $(0.470)$ & $(0.471)$ \\
& $-1.950^{* *}$ & $-2.085^{* *}$ & -1.187 & $-2.747^{* *}$ & $-1.712^{*}$ & $-1.802^{*}$ & $-1.726^{*}$ \\
PAIDcross $_{t-0}$ & $(0.687)$ & $(0.730)$ & $(0.758)$ & $(0.738)$ & $(0.796)$ & $(0.828)$ & $(0.829)$ \\
& $2.386^{* *}$ & $2.464^{* *}$ & $2.396^{* *}$ & $2.630^{* *}$ & $2.426^{* *}$ & $2.371^{* *}$ & $2.507^{* *}$ \\
PAIDcross $_{t-1}$ & $(0.679)$ & $(0.633)$ & $(0.709)$ & $(0.733)$ & $(0.669)$ & $(0.657)$ & $(0.665)$ \\
& 2.957 & $2.932+$ & $2.893+$ & 3.055 & $2.830+$ & $2.706+$ & $2.932+$ \\
PAIDcross $_{t-2}$ & $(1.807)$ & $(1.507)$ & $(1.493)$ & $(1.856)$ & $(1.493)$ & $(1.520)$ & $(1.511)$ \\
& $3.373^{*}$ & $4.039^{*}$ & $3.607+$ & $3.704^{*}$ & $4.066^{*}$ & $3.757+$ & $4.053^{*}$ \\
PAIDcross $_{t-3}$ & $(1.683)$ & $(1.857)$ & $(1.943)$ & $(1.792)$ & $(1.875)$ & $(1.913)$ & $(1.937)$ \\
& $2.774^{* *}$ & $3.358^{* *}$ & $3.126^{* *}$ & $2.872^{* *}$ & $3.165^{* *}$ & $3.086^{* *}$ & $3.289^{* *}$
\end{tabular}




\begin{tabular}{|c|c|c|c|c|c|c|c|}
\hline Lag of dep. var. & $\begin{array}{l}0.733^{* *} \\
(0.038)\end{array}$ & $\begin{array}{l}0.784^{* *} \\
(0.036)\end{array}$ & $\begin{array}{l}0.852^{* *} \\
(0.022)\end{array}$ & $\begin{array}{l}0.918^{* *} \\
(0.015)\end{array}$ & $\begin{array}{l}0.930^{* *} \\
(0.011)\end{array}$ & $\begin{array}{l}0.929^{* *} \\
(0.012)\end{array}$ & $\begin{array}{l}0.927^{* *} \\
(0.012)\end{array}$ \\
\hline Salary & $\begin{array}{l}0.154^{* *} \\
(0.031)\end{array}$ & $\begin{array}{l}0.174^{* * *} \\
(0.035)\end{array}$ & & & & & \\
\hline Asset & $\begin{array}{l}0.076^{* * *} \\
(0.022)\end{array}$ & & $\begin{array}{l}0.102^{* *} \\
(0.033)\end{array}$ & & & & \\
\hline Av. Age & $\begin{array}{l}-0.007^{* *} \\
(0.001)\end{array}$ & & & $\begin{array}{l}-0.007^{* *} \\
(0.001)\end{array}$ & & & \\
\hline$R O A$ & $\begin{array}{l}0.003^{* *} \\
(0.001)\end{array}$ & & & & $\begin{array}{l}0.005^{* *} \\
(0.001)\end{array}$ & & \\
\hline Job applicants & $\begin{array}{l}-0.003 \\
(0.011)\end{array}$ & & & & & $\begin{array}{l}-0.048^{* *} \\
(0.012)\end{array}$ & \\
\hline Nominal wage & $\begin{array}{l}0.001 \\
(0.022)\end{array}$ & & & & & & $\begin{array}{l}-0.005 \\
(0.022)\end{array}$ \\
\hline Constant & $\begin{array}{l}-0.247 \\
(0.376)\end{array}$ & $\begin{array}{l}-0.051 \\
(0.146)\end{array}$ & $\begin{array}{l}-0.425 \\
(0.394)\end{array}$ & $\begin{array}{l}0.895^{* *} \\
(0.137)\end{array}$ & $\begin{array}{l}0.509^{* *} \\
(0.081)\end{array}$ & $\begin{array}{l}1.036^{* *} \\
(0.162)\end{array}$ & $\begin{array}{l}0.557^{* * *} \\
(0.141)\end{array}$ \\
\hline Observations & 2,352 & 2,464 & 2,472 & 2,354 & 2,472 & 2,472 & 2,472 \\
\hline$R$-squared & 0.958 & 0.953 & 0.948 & 0.948 & 0.946 & 0.945 & 0.945 \\
\hline $\begin{array}{l}\text { Number of } \\
\text { banks }\end{array}$ & 172 & 175 & 175 & 172 & 175 & 175 & 175 \\
\hline
\end{tabular}

Note: Estimation results of the eq. (2) that shows the effect of injection and repayment of capital on the number of employees on an unconsolidated basis. The model in the first column includes all of the control variables while those for the remainder columns include one control variable at a time. Robust standard errors in parentheses are clustered at the bank level.

*: $p<0.01$

$* p<0.05$,

$+p<0.1$.

Table 5: Effects of capital injection and repayment on the number of employees -consolidated basis.

\begin{tabular}{|c|c|c|c|c|c|c|c|}
\hline Equation & (3) & (3) & (3) & (3) & (3) & (3) & (3) \\
\hline INJcross $_{t-2}$ & $\begin{array}{l}0.458 \\
(1.173)\end{array}$ & $\begin{array}{l}1.758 \\
(1.363)\end{array}$ & $\begin{array}{l}-0.816 \\
(1.519)\end{array}$ & $\begin{array}{l}0.857 \\
(1.370)\end{array}$ & $\begin{array}{l}1.016 \\
(1.410)\end{array}$ & $\begin{array}{l}0.938 \\
(1.367)\end{array}$ & $\begin{array}{l}0.908 \\
(1.400)\end{array}$ \\
\hline INJ $\operatorname{cross}_{t-3}$ & $\begin{array}{l}-1.307 \\
(1.028)\end{array}$ & $\begin{array}{l}-0.726 \\
(1.424)\end{array}$ & $\begin{array}{l}-1.931+ \\
(1.058)\end{array}$ & $\begin{array}{l}-1.753+ \\
(0.987)\end{array}$ & $\begin{array}{l}-1.609 \\
(1.171)\end{array}$ & $\begin{array}{l}-1.561 \\
(1.125)\end{array}$ & $\begin{array}{l}-1.540 \\
(1.133)\end{array}$ \\
\hline PAIDcross $_{t-0}$ & $\begin{array}{l}0.539 \\
(1.236)\end{array}$ & $\begin{array}{l}-1.146 \\
(1.639)\end{array}$ & $\begin{array}{l}-1.292 \\
(1.467)\end{array}$ & $\begin{array}{l}-0.535 \\
(1.850)\end{array}$ & $\begin{array}{l}-2.034 \\
(1.927)\end{array}$ & $\begin{array}{l}-2.176 \\
(1.957)\end{array}$ & $\begin{array}{l}-2.082 \\
(1.943)\end{array}$ \\
\hline PAIDcross $_{t-1}$ & $\begin{array}{l}2.409+ \\
(1.287)\end{array}$ & $\begin{array}{l}0.519 \\
(1.475)\end{array}$ & $\begin{array}{l}0.377 \\
(1.348)\end{array}$ & $\begin{array}{l}1.582 \\
(2.353)\end{array}$ & $\begin{array}{l}0.097 \\
(1.865)\end{array}$ & $\begin{array}{l}-0.138 \\
(1.918)\end{array}$ & $\begin{array}{l}0.061 \\
(1.879)\end{array}$ \\
\hline PAIDcross $_{t-2}$ & $\begin{array}{l}1.515 \\
(1.190)\end{array}$ & $\begin{array}{l}2.116 \\
(1.350)\end{array}$ & $\begin{array}{l}0.171 \\
(1.151)\end{array}$ & $\begin{array}{l}3.172^{*} \\
(1.472)\end{array}$ & $\begin{array}{l}2.312^{*} \\
(0.939)\end{array}$ & $\begin{array}{l}2.110^{*} \\
(0.902)\end{array}$ & $\begin{array}{l}2.347^{*} \\
(0.919)\end{array}$ \\
\hline PAIDcross $_{t-3}$ & $\begin{array}{l}6.869+ \\
(4.083)\end{array}$ & $\begin{array}{l}6.957^{*} \\
(3.398)\end{array}$ & $\begin{array}{l}6.153+ \\
(3.318)\end{array}$ & $\begin{array}{l}8.340+ \\
(4.341)\end{array}$ & $\begin{array}{l}7.700^{*} \\
(3.462)\end{array}$ & $\begin{array}{l}7.517^{*} \\
(3.500)\end{array}$ & $\begin{array}{l}7.647^{*} \\
(3.455)\end{array}$ \\
\hline Lag of dep. var. & $\begin{array}{l}0.204 \\
(0.152)\end{array}$ & $\begin{array}{l}0.285 \\
(0.183)\end{array}$ & $\begin{array}{l}0.280 \\
(0.183)\end{array}$ & $\begin{array}{l}0.298 \\
(0.194)\end{array}$ & $\begin{array}{l}0.352+ \\
(0.205)\end{array}$ & $\begin{array}{l}0.353+ \\
(0.204)\end{array}$ & $\begin{array}{l}0.353+ \\
(0.204)\end{array}$ \\
\hline Salary & $\begin{array}{l}0.318^{* *} \\
(0.063)\end{array}$ & $\begin{array}{l}0.401^{* *} \\
(0.091)\end{array}$ & & & & & \\
\hline Asset & $\begin{array}{l}0.346^{* *} \\
(0.103)\end{array}$ & & $\begin{array}{l}0.490^{* *} \\
(0.122)\end{array}$ & & & & \\
\hline Av. Age & $\begin{array}{l}-0.016^{* *} \\
(0.005)\end{array}$ & & & $\begin{array}{l}-0.022^{* *} \\
(0.007)\end{array}$ & & & \\
\hline$R O A$ & $\begin{array}{l}-0.002 \\
(0.005)\end{array}$ & & & & $\begin{array}{l}-0.003 \\
(0.007)\end{array}$ & & \\
\hline Job applicants & $\begin{array}{l}0.002 \\
(0.030)\end{array}$ & & & & & $\begin{array}{l}-0.049 \\
(0.037)\end{array}$ & \\
\hline Nominal wage & $\begin{array}{l}0.025 \\
(0.046)\end{array}$ & & & & & & $\begin{array}{l}0.006 \\
(0.048)\end{array}$ \\
\hline Constant & $\begin{array}{l}-1.637 \\
(1.626)\end{array}$ & $\begin{array}{l}1.615^{*} \\
(0.709)\end{array}$ & $\begin{array}{l}-1.836+ \\
(0.999)\end{array}$ & $\begin{array}{l}6.135^{* *} \\
(1.699)\end{array}$ & $\begin{array}{l}4.856^{* *} \\
(1.529)\end{array}$ & $\begin{array}{l}5.395^{* *} \\
(1.630)\end{array}$ & $\begin{array}{l}4.815^{* *} \\
(1.527)\end{array}$ \\
\hline Observations & 1,107 & 1,212 & 1,215 & 1,109 & 1,215 & 1,215 & 1,215 \\
\hline$R$-squared & 0.671 & 0.621 & 0.597 & 0.543 & 0.522 & 0.523 & 0.522 \\
\hline $\begin{array}{l}\text { Number of } \\
\text { banks }\end{array}$ & 147 & 150 & 150 & 147 & 150 & 150 & 150 \\
\hline
\end{tabular}


Note: Estimation results of eq. (3) that shows the effect of injection and repayment of capital on the number of employees on a consolidated basis. The model in the first column includes all of the control variables while those for the remainder columns include one control variable at a time. Robust standard errors in parentheses are clustered at the bank level.

** $p<0.01$,

$* p<0.05$,

$+p<0.1$.

Table 6: Robustness check: GMM estimation.

\begin{tabular}{|c|c|c|c|}
\hline Model & $\begin{array}{l}\text { (1) } \\
\text { Age }\end{array}$ & $\begin{array}{l}\text { (2) } \\
\text { logofemployee }\end{array}$ & $\begin{array}{l}\text { (3) } \\
\text { logofemployee }\end{array}$ \\
\hline INJcross $_{t-0}$ & $\begin{array}{l}53.762 \\
(94.175)\end{array}$ & $\begin{array}{l}0.211 \\
(0.460)\end{array}$ & \\
\hline INJcross $_{t-1}$ & $\begin{array}{l}59.4 \\
(54.172)\end{array}$ & $\begin{array}{l}-0.968 \\
(0.949)\end{array}$ & \\
\hline INJcross $_{t-2}$ & $\begin{array}{l}-26.868^{* *} \\
(9.477)\end{array}$ & $\begin{array}{l}-0.918 \\
(0.881)\end{array}$ & $\begin{array}{l}2.174 \\
(1.619)\end{array}$ \\
\hline INJcross $_{t-3}$ & $\begin{array}{l}-14.599^{*} \\
(6.585)\end{array}$ & $\begin{array}{l}-1.141^{* *} \\
(0.369)\end{array}$ & $\begin{array}{l}-0.131 \\
(1.163)\end{array}$ \\
\hline PAIDcross $_{t-0}$ & $\begin{array}{l}37.995+ \\
(21.052)\end{array}$ & $\begin{array}{l}0.887+ \\
(0.454)\end{array}$ & $\begin{array}{l}0.682 \\
(0.798)\end{array}$ \\
\hline PAIDcross $_{t-1}$ & $\begin{array}{l}-3.249 \\
(15.339)\end{array}$ & $\begin{array}{l}0.227 \\
(1.601)\end{array}$ & $\begin{array}{l}0.935 \\
(1.145)\end{array}$ \\
\hline PAIDcross $_{t-2}$ & $\begin{array}{l}-42.163 \\
(25.680)\end{array}$ & $\begin{array}{l}2.451 \\
(1.755)\end{array}$ & $\begin{array}{l}-0.856 \\
(1.878)\end{array}$ \\
\hline PAIDcross $_{t-3}$ & $\begin{array}{l}-7.877 \\
(14.024)\end{array}$ & $\begin{array}{l}1.345^{*} \\
(0.674)\end{array}$ & $\begin{array}{l}3.275 \\
(3.244)\end{array}$ \\
\hline Lagof Age & $\begin{array}{l}0.985^{* *} \\
(0.067)\end{array}$ & & \\
\hline Lagoflogofemployee UN & & $\begin{array}{l}0.328+ \\
(0.169)\end{array}$ & \\
\hline Lagoflogofemployee CON & & & $\begin{array}{l}0.500^{* *} \\
(0.152)\end{array}$ \\
\hline Observations & 2222 & 2215 & 1107 \\
\hline Number of bank & 170 & 169 & 147 \\
\hline Hansen test ( $p$-value) & 1 & 0.259 & 0.0856 \\
\hline $\operatorname{AR}(2)$ test ( $p$-value) & 0.0976 & 0.177 & 0.371 \\
\hline Number of instruments & 77 & 43 & 115 \\
\hline
\end{tabular}

Note: Estimation results of system GMM estimations which examine the effect of the capital injection and repayment on: bank's employees' average age (eq. (1)), the number of employees on an unconsolidated basis (eq. (2)), and on consolidated basis (eq. (3)). For each of the models, we created a vector of instrumental variables as well as a vector of GMM variables. The variables in the latter are instrumented with their own lags. Robust standard errors in parentheses are clustered at the bank level.

*** $p<0.01$

${ }^{*} p<0.05$

$+p<0.1$

Table 7: Balance test.

\begin{tabular}{|c|c|c|c|c|}
\hline & Before & After & Before & After \\
\hline Variable & \multicolumn{2}{|c|}{ Age_1997 } & \multicolumn{2}{|c|}{ Age_1998 } \\
\hline Treatment & 36.05 & 36.05 & 36.74 & 36.74 \\
\hline Control & 35.97 & 36.44 & 36.40 & 37.01 \\
\hline \multirow{2}{*}{$p$-value } & $(0.88)$ & $(0.33)$ & $(0.48)$ & $(0.58)$ \\
\hline & \multicolumn{2}{|c|}{ Employee_1997 } & \multicolumn{2}{|c|}{ Employee_1998 } \\
\hline Treatment & $4,123.3$ & $4,123.3$ & $3,932.2$ & $3,932.2$ \\
\hline Control & $1,912.4$ & $2,364.8$ & $1,860.1$ & $2,287.4$ \\
\hline \multirow[t]{2}{*}{$p$-value } & (0.13) & $(0.14)$ & (0.13) & $(0.14)$ \\
\hline & \multicolumn{2}{|c|}{ ROA_1997 } & \multicolumn{2}{|c|}{ ROA_1998 } \\
\hline Treatment & -0.38 & -0.38 & -0.85 & 0.85 \\
\hline Control & 0.22 & 0.07 & 0.05 & -0.39 \\
\hline \multirow[t]{2}{*}{$p$-value } & $(0.03)$ & $(0.03)$ & $(0.00)$ & $(0.02)$ \\
\hline & \multicolumn{2}{|c|}{ Size_1997 } & \multicolumn{2}{|c|}{ Size_1998 } \\
\hline
\end{tabular}




\begin{tabular}{|c|c|c|c|c|}
\hline Treatment & 15.39 & 15.39 & 15.38 & 15.38 \\
\hline Control & 14.26 & 14.69 & 14.29 & 14.69 \\
\hline \multirow[t]{2}{*}{$p$-value } & $(0.01)$ & $(0.03)$ & $(0.01)$ & $(0.04)$ \\
\hline & JobApplicants_1997 & & JobApplicants_1998 & \\
\hline Treatment & 115,916 & 115,916 & 122,507 & 122,507 \\
\hline Control & 40,597 & 70,901 & 43,179 & 74848 \\
\hline$p$-value & $(0.00)$ & $(0.02)$ & $(0.00)$ & $(0.02)$ \\
\hline
\end{tabular}

Note: This table shows means of variables for the injected and non-injected samples before and after the matching. "Before" and "After" indicates before and after matching, respectively. "Treatment" and "Control" indicate the injected and non-injected sample, respectively. Numbers in parentheses are for $t$-tests for the difference in means of each variable between the treatment and control sample.

Table 8: PSM: effects of capital injection and repayment on the average age of employees.

\begin{tabular}{|c|c|c|c|c|c|c|c|}
\hline Equation & (1) & (1) & (1) & (1) & (1) & (1) & (1) \\
\hline INJCross $_{t-0}$ & $\begin{array}{l}11.903 \\
(21.052)\end{array}$ & $\begin{array}{l}-10.281 \\
(16.476)\end{array}$ & $\begin{array}{l}-6.081 \\
(13.737)\end{array}$ & $\begin{array}{l}-7.765 \\
(17.638)\end{array}$ & $\begin{array}{l}10.324 \\
(18.296)\end{array}$ & $\begin{array}{l}-9.206 \\
(15.670)\end{array}$ & $\begin{array}{l}-8.556 \\
(15.827)\end{array}$ \\
\hline INJ rross $_{t-1}$ & $\begin{array}{l}34.942 \\
(22.294)\end{array}$ & $\begin{array}{l}17.820 \\
(12.888)\end{array}$ & $\begin{array}{l}19.254 \\
(11.978)\end{array}$ & $\begin{array}{l}35.400 \\
(22.191)\end{array}$ & $\begin{array}{l}20.480+ \\
(11.452)\end{array}$ & $\begin{array}{l}19.998+ \\
(11.660)\end{array}$ & $\begin{array}{l}20.426+ \\
(11.912)\end{array}$ \\
\hline$I^{N} \operatorname{Jcross}_{t-2}$ & $\begin{array}{l}-15.363 \\
(16.742)\end{array}$ & $\begin{array}{l}-13.526 \\
(15.475)\end{array}$ & $\begin{array}{l}-14.355 \\
(15.179)\end{array}$ & $\begin{array}{l}-14.844 \\
(16.170)\end{array}$ & $\begin{array}{l}-13.651 \\
(16.476)\end{array}$ & $\begin{array}{l}-11.289 \\
(16.171)\end{array}$ & $\begin{array}{l}-11.562 \\
(16.052)\end{array}$ \\
\hline INJcross $_{t-3}$ & $\begin{array}{l}-25.040^{* * *} \\
(3.686)\end{array}$ & $\begin{array}{l}-22.503^{* *} \\
(3.172)\end{array}$ & $\begin{array}{l}-23.857^{* *} \\
(2.981)\end{array}$ & $\begin{array}{l}-25.256^{* *} \\
(3.508)\end{array}$ & $\begin{array}{l}-21.767^{* * *} \\
(2.956)\end{array}$ & $\begin{array}{l}-19.981^{* * *} \\
(2.919)\end{array}$ & $\begin{array}{l}-20.579 * * \\
(2.822)\end{array}$ \\
\hline PAIDcross $_{t-0}$ & $\begin{array}{l}18.968 \\
(31.674)\end{array}$ & $\begin{array}{l}20.065 \\
(32.273)\end{array}$ & $\begin{array}{l}21.063 \\
(32.580)\end{array}$ & $\begin{array}{l}15.599 \\
(30.641)\end{array}$ & $\begin{array}{l}23.851 \\
(32.838)\end{array}$ & $\begin{array}{l}24.728 \\
(33.279)\end{array}$ & $\begin{array}{l}23.787 \\
(32.758)\end{array}$ \\
\hline PAIDcross $_{t-1}$ & $\begin{array}{l}-33.220^{* *} \\
(6.297)\end{array}$ & $\begin{array}{l}-35.733^{* *} \\
(6.673)\end{array}$ & $\begin{array}{l}-35.029^{* *} \\
(6.954)\end{array}$ & $\begin{array}{l}-37.343^{* *} \\
(5.174)\end{array}$ & $\begin{array}{l}-32.275^{* *} \\
(6.880)\end{array}$ & $\begin{array}{l}-30.713^{* *} \\
(7.494)\end{array}$ & $\begin{array}{l}-32.463^{* *} \\
(6.778)\end{array}$ \\
\hline PAIDcross $_{t-2}$ & $\begin{array}{l}-84.708^{* *} \\
(13.969)\end{array}$ & $\begin{array}{l}-92.439^{* *} \\
(11.981)\end{array}$ & $\begin{array}{l}-89.989^{* *} \\
(13.783)\end{array}$ & $\begin{array}{l}-90.608^{* *} \\
(12.614)\end{array}$ & $\begin{array}{l}-89.090^{* *} \\
(12.673)\end{array}$ & $\begin{array}{l}-87.295^{* *} \\
(11.771)\end{array}$ & $\begin{array}{l}-89.300^{* *} \\
(12.360)\end{array}$ \\
\hline PAIDcross $_{t-3}$ & $\begin{array}{l}-43.623^{* *} \\
(11.796)\end{array}$ & $\begin{array}{l}-46.653^{* *} \\
(10.468)\end{array}$ & $\begin{array}{l}-46.675^{* *} \\
(11.364)\end{array}$ & $\begin{array}{l}-46.654^{* *} \\
(10.958)\end{array}$ & $\begin{array}{l}-44.502^{* *} \\
(10.641)\end{array}$ & $\begin{array}{l}-42.776^{* *} \\
(10.396)\end{array}$ & $\begin{array}{l}-44.671^{* *} \\
(10.568)\end{array}$ \\
\hline Lag of dep. var. & $\begin{array}{l}0.787^{* *} \\
(0.036)\end{array}$ & $\begin{array}{l}0.829^{* *} \\
(0.032)\end{array}$ & $\begin{array}{l}0.814^{* *} \\
(0.031)\end{array}$ & $\begin{array}{l}0.796^{* *} \\
(0.033)\end{array}$ & $\begin{array}{l}0.838^{* *} \\
(0.032)\end{array}$ & $\begin{array}{l}0.831^{* *} \\
(0.034)\end{array}$ & $\begin{array}{l}0.836^{* *} \\
(0.033)\end{array}$ \\
\hline Salary & $\begin{array}{l}0.442 \\
(0.348)\end{array}$ & $\begin{array}{l}-0.315 \\
(0.216)\end{array}$ & & & & & \\
\hline Asset & $\begin{array}{l}-0.220 \\
(0.274)\end{array}$ & & $\begin{array}{l}-0.493^{*} \\
(0.197)\end{array}$ & & & & \\
\hline Employees ${ }^{U N}$ & $\begin{array}{l}-1.076+ \\
(0.547)\end{array}$ & & & $\begin{array}{l}-0.940^{* *} \\
(0.287)\end{array}$ & & & \\
\hline$R O A$ & $\begin{array}{l}0.038 \\
(0.023)\end{array}$ & & & & $\begin{array}{l}0.042+ \\
(0.022)\end{array}$ & & \\
\hline Job applicants & $\begin{array}{l}0.499 \\
(0.399)\end{array}$ & & & & & $\begin{array}{l}0.472 \\
(0.408)\end{array}$ & \\
\hline Nominal wage & $\begin{array}{l}-0.360 \\
(0.545)\end{array}$ & & & & & & $\begin{array}{l}0.009 \\
(0.608)\end{array}$ \\
\hline Constant & $\begin{array}{l}12.065+ \\
(6.436)\end{array}$ & $\begin{array}{l}9.632^{* *} \\
(2.489)\end{array}$ & $\begin{array}{l}14.580^{* *} \\
(3.548)\end{array}$ & $\begin{array}{l}14.884^{* *} \\
(2.893)\end{array}$ & $\begin{array}{l}6.296^{* *} \\
(1.270)\end{array}$ & $\begin{array}{l}1.370 \\
(4.268)\end{array}$ & $\begin{array}{l}6.316 \\
(4.135)\end{array}$ \\
\hline Observations & 713 & 714 & 714 & 713 & 714 & 714 & 714 \\
\hline$R$-squared & 0.919 & 0.916 & 0.917 & 0.918 & 0.916 & 0.916 & 0.915 \\
\hline $\begin{array}{l}\text { Number of } \\
\text { banks }\end{array}$ & 40 & 40 & 40 & 40 & 40 & 40 & 40 \\
\hline
\end{tabular}

Note: Using propensity score matching (PSM) to determine a comparable sample of non-injected banks, we estimate the effect of "injection" and

"repayment" on average employee's age (eq. (1)) of injected banks using a sample of 40 banks. Robust standard errors in parentheses are clustered at the bank level.

$* 0<0.01$

${ }^{*} p<0.05$

$+p<0.1$

Table 9: PSM: effects of capital injection and repayment on the number of employees (unconsolidated basis).

\begin{tabular}{llllllll}
\hline Equation & $\mathbf{( 2 )}$ & $\mathbf{( 2 )}$ & $\mathbf{( 2 )}$ & $\mathbf{( 2 )}$ & $\mathbf{( 2 )}$ & $\mathbf{( 2 )}$ & $\mathbf{( 2 )}$ \\
\hline$I N J \operatorname{cross}_{t-0}$ & 0.674 & -0.907 & $-3.802+$ & -1.817 & -1.866 & $-3.408+$ & $-3.528+$
\end{tabular}




\begin{tabular}{|c|c|c|c|c|c|c|c|}
\hline & $(0.806)$ & $(0.943)$ & $(1.980)$ & (1.373) & $(1.843)$ & (1.885) & $(1.870)$ \\
\hline INJcross $_{t-1}$ & $\begin{array}{l}-5.352^{*} \\
(2.340)\end{array}$ & $\begin{array}{l}-6.033^{*} \\
(2.736)\end{array}$ & $\begin{array}{l}-8.278^{* *} \\
(1.769)\end{array}$ & $\begin{array}{l}-6.064^{*} \\
(2.928)\end{array}$ & $\begin{array}{l}-8.329^{* *} \\
(1.789)\end{array}$ & $\begin{array}{l}-8.298^{* *} \\
(1.829)\end{array}$ & $\begin{array}{l}-8.372^{* *} \\
(1.811)\end{array}$ \\
\hline INJcross $_{t-2}$ & $\begin{array}{l}-2.337^{* *} \\
(0.468)\end{array}$ & $\begin{array}{l}-1.636^{* *} \\
(0.355)\end{array}$ & $\begin{array}{l}0.328 \\
(0.763)\end{array}$ & $\begin{array}{l}-1.738^{* *} \\
(0.374)\end{array}$ & $\begin{array}{l}0.316 \\
(0.714)\end{array}$ & $\begin{array}{l}0.335 \\
(0.687)\end{array}$ & $\begin{array}{l}0.391 \\
(0.722)\end{array}$ \\
\hline INJcross $_{t-3}$ & $\begin{array}{l}-1.187^{* *} \\
(0.407)\end{array}$ & $\begin{array}{l}-1.021^{*} \\
(0.479)\end{array}$ & $\begin{array}{l}-0.479 \\
(0.885)\end{array}$ & $\begin{array}{l}-1.722^{* *} \\
(0.496)\end{array}$ & $\begin{array}{l}-0.747 \\
(0.863)\end{array}$ & $\begin{array}{l}-0.776 \\
(0.878)\end{array}$ & $\begin{array}{l}-0.661 \\
(0.882)\end{array}$ \\
\hline PAIDcross $_{t-0}$ & $\begin{array}{l}0.842^{*} \\
(0.395)\end{array}$ & $\begin{array}{l}1.702^{* * *} \\
(0.574)\end{array}$ & $\begin{array}{l}0.885^{*} \\
(0.396)\end{array}$ & $\begin{array}{l}0.855^{*} \\
(0.328)\end{array}$ & $\begin{array}{l}1.276^{* *} \\
(0.265)\end{array}$ & $\begin{array}{l}1.034^{* *} \\
(0.328)\end{array}$ & $\begin{array}{l}1.245^{* *} \\
(0.299)\end{array}$ \\
\hline PAIDcross $_{t-1}$ & $\begin{array}{l}1.766^{*} \\
(0.661)\end{array}$ & $\begin{array}{l}2.724^{* *} \\
(0.847)\end{array}$ & $\begin{array}{l}1.994^{* *} \\
(0.598)\end{array}$ & $\begin{array}{l}1.616^{* *} \\
(0.411)\end{array}$ & $\begin{array}{l}2.280^{* *} \\
(0.435)\end{array}$ & $\begin{array}{l}1.933^{* *} \\
(0.510)\end{array}$ & $\begin{array}{l}2.231^{* * *} \\
(0.465)\end{array}$ \\
\hline PAIDcross $_{t-2}$ & $\begin{array}{l}4.790^{* * *} \\
(1.478)\end{array}$ & $\begin{array}{l}6.672^{* * *} \\
(1.090)\end{array}$ & $\begin{array}{l}5.769^{* *} \\
(1.832)\end{array}$ & $\begin{array}{l}4.929^{*} \\
(1.927)\end{array}$ & $\begin{array}{l}6.269^{* *} \\
(1.762)\end{array}$ & $\begin{array}{l}5.868^{* *} \\
(1.727)\end{array}$ & $\begin{array}{l}6.245^{* *} \\
(1.777)\end{array}$ \\
\hline PAIDcross $_{t-3}$ & $\begin{array}{l}1.607^{* * *} \\
(0.473)\end{array}$ & $\begin{array}{l}3.300^{* * *} \\
(0.485)\end{array}$ & $\begin{array}{l}2.765^{* * *} \\
(0.324)\end{array}$ & $\begin{array}{l}1.574^{* * *} \\
(0.498)\end{array}$ & $\begin{array}{l}2.955^{* *} \\
(0.316)\end{array}$ & $\begin{array}{l}2.559^{* * *} \\
(0.333)\end{array}$ & $\begin{array}{l}2.938^{* *} \\
(0.337)\end{array}$ \\
\hline Lag of dep. var. & $\begin{array}{l}0.769^{* *} \\
(0.036)\end{array}$ & $\begin{array}{l}0.848^{* *} \\
(0.035)\end{array}$ & $\begin{array}{l}0.907^{* *} \\
(0.022)\end{array}$ & $\begin{array}{l}0.937^{* *} \\
(0.023)\end{array}$ & $\begin{array}{l}0.962^{* *} \\
(0.018)\end{array}$ & $\begin{array}{l}0.956^{* *} \\
(0.018)\end{array}$ & $\begin{array}{l}0.960^{* *} \\
(0.018)\end{array}$ \\
\hline Salary & $\begin{array}{l}0.146^{* *} \\
(0.021)\end{array}$ & $\begin{array}{l}0.145^{* *} \\
(0.026)\end{array}$ & & & & & \\
\hline Asset & $\begin{array}{l}0.053^{*} \\
(0.024)\end{array}$ & & $\begin{array}{l}0.052^{*} \\
(0.020)\end{array}$ & & & & \\
\hline Av. Age & $\begin{array}{l}-0.008^{* *} \\
(0.002)\end{array}$ & & & $\begin{array}{l}-0.008^{* *} \\
(0.002)\end{array}$ & & & \\
\hline$R O A$ & $\begin{array}{l}0.004^{* *} \\
(0.001)\end{array}$ & & & & $\begin{array}{l}0.004^{*} \\
(0.002)\end{array}$ & & \\
\hline Job applicants & $\begin{array}{l}0.004 \\
(0.019)\end{array}$ & & & & & $\begin{array}{l}-0.070^{* *} \\
(0.018)\end{array}$ & \\
\hline Nominal wage & $\begin{array}{l}-0.007 \\
(0.042)\end{array}$ & & & & & & $\begin{array}{l}-0.020 \\
(0.044)\end{array}$ \\
\hline Constant & $\begin{array}{l}-0.152 \\
(0.520)\end{array}$ & $\begin{array}{l}-0.211 \\
(0.197)\end{array}$ & $\begin{array}{l}-0.060 \\
(0.234)\end{array}$ & $\begin{array}{l}0.776^{* *} \\
(0.218)\end{array}$ & $\begin{array}{l}0.300^{*} \\
(0.134)\end{array}$ & $\begin{array}{l}1.137^{* * *} \\
(0.246)\end{array}$ & $\begin{array}{l}0.444 \\
(0.293)\end{array}$ \\
\hline Observations & 713 & 743 & 747 & 713 & 747 & 747 & 747 \\
\hline$R$-squared & 0.977 & 0.974 & 0.970 & 0.972 & 0.970 & 0.970 & 0.969 \\
\hline $\begin{array}{l}\text { Number of } \\
\text { banks }\end{array}$ & 40 & 40 & 40 & 40 & 40 & 40 & 40 \\
\hline
\end{tabular}

Note: Using propensity score matching (PSM) to determine a comparable sample of non-injected banks, we estimate the effect of "injection" and

"repayment" on the number employees (eq. (2) of injected banks using a sample of 40 banks). The results are on an unconsolidated basis. Robust standard errors in parentheses are clustered at the bank level.

* $p<0.01$

$* p<0.05$,

$+p<0.1$

Table 10: PSM: effects of capital injection and repayment on the number of employees (consolidated basis).

\begin{tabular}{llllllll}
\hline Equation & $\mathbf{( 3 )}$ & $\mathbf{( 3 )}$ & $\mathbf{( 3 )}$ & $\mathbf{( 3 )}$ & $\mathbf{( 3 )}$ & $\mathbf{( 3 )}$ & $\mathbf{( 3 )}$ \\
\hline INJcross $_{t-2}$ & $1.775+$ & $2.387+$ & 0.955 & 1.517 & 1.614 & 1.627 & 1.590 \\
& $(1.029)$ & $(1.364)$ & $(1.190)$ & $(0.931)$ & $(1.273)$ & $(1.213)$ & $(1.239)$ \\
INJcross $_{t-3}$ & -0.440 & 0.150 & -1.040 & $-1.047^{*}$ & -0.720 & -0.795 & -0.744 \\
& $(0.530)$ & $(0.683)$ & $(0.665)$ & $(0.403)$ & $(0.641)$ & $(0.623)$ & $(0.610)$ \\
PAIDcross $_{t-0}$ & 1.167 & 0.991 & -0.439 & 0.049 & -0.583 & -0.764 & -0.594 \\
& $(1.173)$ & $(0.971)$ & $(0.903)$ & $(1.289)$ & $(1.036)$ & $(0.978)$ & $(1.008)$ \\
PAIDcross $_{t-1}$ & $1.651+$ & $1.685^{*}$ & 0.614 & 0.450 & 0.238 & -0.076 & 0.166 \\
& $(0.946)$ & $(0.820)$ & $(1.042)$ & $(1.190)$ & $(1.041)$ & $(1.006)$ & $(0.964)$ \\
PAIDcross $_{t-2}$ & $6.320^{*}$ & $7.433^{*}$ & $5.711^{*}$ & $5.347+$ & $6.277^{*}$ & $5.908+$ & $6.383^{*}$ \\
& $(2.816)$ & $(3.118)$ & $(2.403)$ & $(2.645)$ & $(2.883)$ & $(2.953)$ & $(2.953)$ \\
PAIDcross $_{t-3}$ & $4.107^{* *}$ & $5.213^{* *}$ & $4.575^{* *}$ & $3.802^{* *}$ & $4.880^{* *}$ & $4.516^{* *}$ & $4.717^{* *}$ \\
& $(0.792)$ & $(0.662)$ & $(0.430)$ & $(0.539)$ & $(0.460)$ & $(0.491)$ & $(0.543)$ \\
Lag of dep. var. $^{* * *}$ & $0.691^{* *}$ & $0.734^{* *}$ & $0.731^{* *}$ & $0.762^{* *}$ & $0.792^{* *}$ & $0.783^{* *}$ & $0.795^{* *}$ \\
Salary & $(0.033)$ & $(0.026)$ & $(0.037)$ & $(0.027)$ & $(0.051)$ & $(0.047)$ & $(0.046)$ \\
Asset & $0.184^{* * *}$ & $0.223^{* *}$ & & & & &
\end{tabular}




\begin{tabular}{|c|c|c|c|c|c|c|c|}
\hline Av. Age & $\begin{array}{l}-0.011^{*} \\
(0.004)\end{array}$ & & & $\begin{array}{l}-0.016^{* *} \\
(0.004)\end{array}$ & & & \\
\hline$R O A$ & $\begin{array}{l}-0.000 \\
(0.004)\end{array}$ & & & & $\begin{array}{l}0.001 \\
(0.004)\end{array}$ & & \\
\hline Job applicants & $\begin{array}{l}-0.015 \\
(0.031)\end{array}$ & & & & & $\begin{array}{l}-0.107^{*} \\
(0.049)\end{array}$ & \\
\hline Nominal wage & $\begin{array}{l}-0.126+ \\
(0.073)\end{array}$ & & & & & & $\begin{array}{l}-0.192^{*} \\
(0.084)\end{array}$ \\
\hline Constant & $\begin{array}{l}0.636 \\
(0.835)\end{array}$ & $\begin{array}{l}-0.076 \\
(0.391)\end{array}$ & $\begin{array}{l}-0.653 \\
(0.921)\end{array}$ & $\begin{array}{l}2.379^{* *} \\
(0.242)\end{array}$ & $\begin{array}{l}1.609^{* *} \\
(0.393)\end{array}$ & $\begin{array}{l}2.894^{* *} \\
(0.708)\end{array}$ & $\begin{array}{l}2.766^{* * *} \\
(0.669)\end{array}$ \\
\hline Observations & 360 & 388 & 388 & 360 & 388 & 388 & 388 \\
\hline$R$-squared & 0.792 & 0.792 & 0.777 & 0.772 & 0.768 & 0.772 & 0.772 \\
\hline Number of & 40 & 40 & 40 & 40 & 40 & 40 & 40 \\
\hline
\end{tabular}

Note: Using propensity score matching (PSM) to determine a comparable sample of non-injected banks, we estimate the effect of "injection" and

"repayment" on the number employees (eq. (3)) of injected banks using a sample of 40 banks. The results are on a consolidated basis. Robust standard errors in parentheses are clustered at the bank level.

*** $p<0.01$

${ }^{*} p<0.05$

$+p<0.1$.

Table 11: Rosenbaum sensitivity test for Wilcoxon signed rank $p$-value. Unconfounded estimate: 0.0421.

\begin{tabular}{lll}
\hline Gamma & Lower bound & Upper bound \\
\hline 1 & 0.0421 & 0.0421 \\
1.1 & 0.0304 & 0.0568 \\
1.2 & 0.0221 & 0.0729 \\
1.3 & 0.016 & 0.0903 \\
1.4 & 0.0117 & 0.1087 \\
1.5 & 0.0085 & 0.1277 \\
\hline
\end{tabular}

Note: Gamma is odds of differential assignment to treatment due to unobserved factors

Table 12: Rosenbaum sensitivity test for Hodges-Lehmann point estimate. Unconfounded estimate: -0.7826.

\begin{tabular}{lll}
\hline Gamma & Lower bound & Upper bound \\
\hline 1 & -0.78261 & -0.78261 \\
1.1 & -0.88261 & -0.58261 \\
1.2 & -0.88261 & -0.58261 \\
1.3 & -0.88261 & -0.58261 \\
1.4 & -0.98261 & -0.58261 \\
1.5 & -0.98261 & -0.58261 \\
\hline
\end{tabular}

Note: Gamma is odds of differential assignment to treatment due to unobserved factors.

\section{Acknowledgment:}

Onji would like to acknowledge research support provided by the Australia-Japan Research Centre and Jenny Corbett. Participants at the ANU-Japan Public Economics Workshop, Osaka University Public Economics Workshop and Hitotsubashi University Center for Financial Research Workshop provided useful feedback. Osada would like to acknowledge the financial support under the Grant-in-Aid for Scientific Research (KAKENHI) No 26780188 provided by the Japan Society for the Promotion of Science. Participants at the WEAI 10th Biennial Pacific Rim Tokyo Conference and Hitotsubashi University Center for Financial Research Workshop provided useful feedback. Vera would like to thank Takeo Hoshi and Masami Imai for providing valuable comments. Participants at Stanford Summer Juku and the WEAI Seattle conference provided useful feedback. 


\section{A Appendix}

A difference-in-differences analysis assumes that the outcome variables in treatment and control groups follow the same time trend before the treatment (i.e. the common pre-treatment trend assumption). If pre-treatment trends are different, our results would be biased.

To visually inspect for pre-treatment trends, we first compare the pre-treatment trend of injected banks to that of all non-injected banks. Figure 3 shows the average employee's age of injected and non-injected banks. Evidently, the average employee's age for both groups follows very similarly trajectories up until 1999. Figure 4 shows the number of employees in logs of injected and non-injected banks on unconsolidated basis. Once again, the trajectories are similar.

We then repeat the visual inspection in the matched sample. ${ }^{19}$ Figure 5 is for the average employee's age, showing a close correspondence during the pre-injection period. Figure 6 is for the number of employees at unconsolidated basis in log. The trajectories are very similar.

To test statistically for the existence of different pre-treatment trends between a treatment group and a control group, we employ a common strategy: estimate a model that incorporates a lead indicator for treatment. If injected and non-injected banks exhibit different pre-treatment time trends, the lead dummy should capture such influence. We estimate the following eqs (4), (5), and (6):

$$
\begin{aligned}
& A g e_{i, t}=\text { Lead }_{i, t}+\sum_{j=0}^{3} \alpha_{j} \text { INJcross }_{i, t-j}+\sum_{j=0}^{3} \beta_{j} \text { PAIDcross }_{i, t-j} \\
& +\gamma A g e_{i, t-1}+X_{i, t}^{\prime} \theta+\kappa+\mu_{i}+\phi_{t}+\epsilon_{i, t}
\end{aligned}
$$

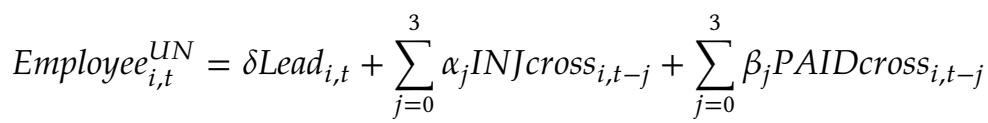

$$
\begin{aligned}
& +\gamma \text { Employee }_{i, t-1}^{U N}+Z_{i, t}^{\prime} \theta+\kappa+\mu_{i}+\phi_{t}+\epsilon_{i, t} \\
& \text { Employee }_{i, t}^{\text {CON }}=\delta \text { Lead }_{i, t}+\sum_{j=0}^{3} \alpha_{j} \text { INJcross }_{i, t-j}+\sum_{j=0}^{3} \beta_{j} \text { PAIDcross }_{i, t-j} \\
& +\gamma \text { Employee }_{i, t-1}^{\mathrm{CON}}+\mathrm{Z}_{i, t}^{\prime} \theta+\kappa+\mu_{i}+\phi_{t}+\epsilon_{i, t},
\end{aligned}
$$

where $\operatorname{Lead}_{i, t}$ takes the value 1 if bank $i$ receives capital injection in time $t+1$. If pre-treatment trends exist, we would expect $\delta$, the coefficient on Lead $_{i, t}$, to be statistically different from zero. Table 13 presents estimates of $\delta$, showing that none of the coefficients is statistically significant. The first column of each Model is for full sample. The second, third, and forth columns are for the PSM sample with the sample size 50, 40, and 30, respectively. These results do not support differences in pre-treatment trends between injected and non-injected banks.

We have considered Autor (2003) "leads-and-lags" model to test for the existence of different pre- and posttreatment trends between injected and non-injected banks. The model includes the interaction terms between year dummies and a dummy for banks which receive injection. The coefficients on interaction terms capture treatment-control differences at different points in time. The application of this approach is not straightforward in our setting, however; the timing of intervention is uniform in Autor (2003) application, but it is heterogeneous in our setting. Specifically, the timing of injections spans 5 years: from 1998 to 2002 (Table 2). The timing of repayments differs across banks and its span is more than 10 years: from 2000 to 2011. The two periods overlap during 1998-2002. Given the overlap, coefficients from the post-1998 period are hard to interpret. At least, coefficients from 1997 and before should capture pre-existing trends, so we focus our discussion on them. We estimate the following eqs (7), (8) and (9):

$$
\begin{aligned}
\text { Age }_{i, t}= & \sum_{j=1992}^{2009} \eta_{j} \text { Treatment }_{i} * \text { Year }_{j} \\
& +\gamma \text { Age }_{i, t-1}+X_{i, t}^{\prime} \theta+\kappa+\mu_{i}+\phi_{t}+\epsilon_{i, t} \\
\text { Employee }_{i, t}^{U N}= & \sum_{j=1992}^{2009} \eta_{j} \text { Treatment }_{i} * \text { Year }_{j} \\
& +\gamma \text { Employee }_{i, t-1}^{U N}+Z_{i, t}^{\prime} \theta+\kappa+\mu_{i}+\phi_{t}+\epsilon_{i, t},
\end{aligned}
$$




$$
\begin{aligned}
\text { Employee }_{i, t}^{\text {CON }}= & \sum_{j=1992}^{2009} \eta_{j} \text { Treatment }_{i} * \text { Year }_{j} \\
& +\gamma \text { Employee }_{i, t-1}^{C O N}+Z_{i, t}^{\prime} \theta+\kappa+\mu_{i}+\phi_{t}+\epsilon_{i, t}
\end{aligned}
$$

where Treatment $_{i}$ is a treatment dummy for banks that are injected during sample period, and $Y_{e a r}$ is a year dummy at year $j$.

Table 14 presents the estimates of $\eta_{j}$ on the interaction terms from the full specification. The first column of each Model is for the full sample, and the second, third, and forth columns are for the PSM sample with the sample size of 50,40, and 30, respectively. While we present the result for consolidated employment for completeness (model 9), the approach is not applicable due to the short sample period. As for model (7) examining the effects on Age, except for the coefficient on 1995, which is statistically significant at the $10 \%$ level, no other coefficients are significant before 1997. For model (8), some estimates in 1996 and 1997 are statistically significant at the $10 \%$ level, but no other coefficients are significant before 1997. Overall, these results further discount the possibility of a systematic difference in pre-treatment trends.

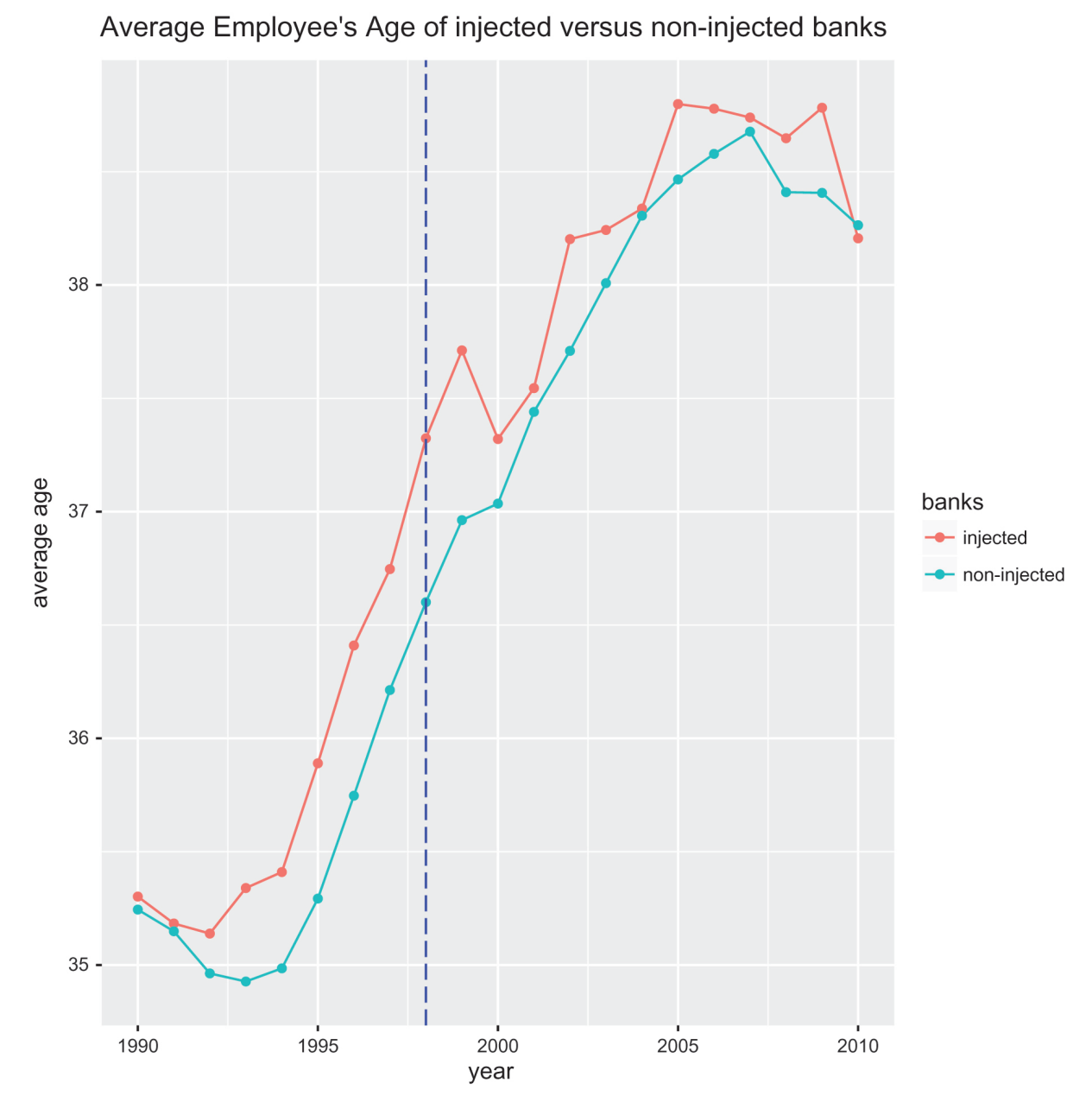

Figure 3: Examinations of pre-treatment trends: graphical analysis.

Source: Authors'own calculations. 
Number of workers of

injected versus non-injected banks (unconsolidated)

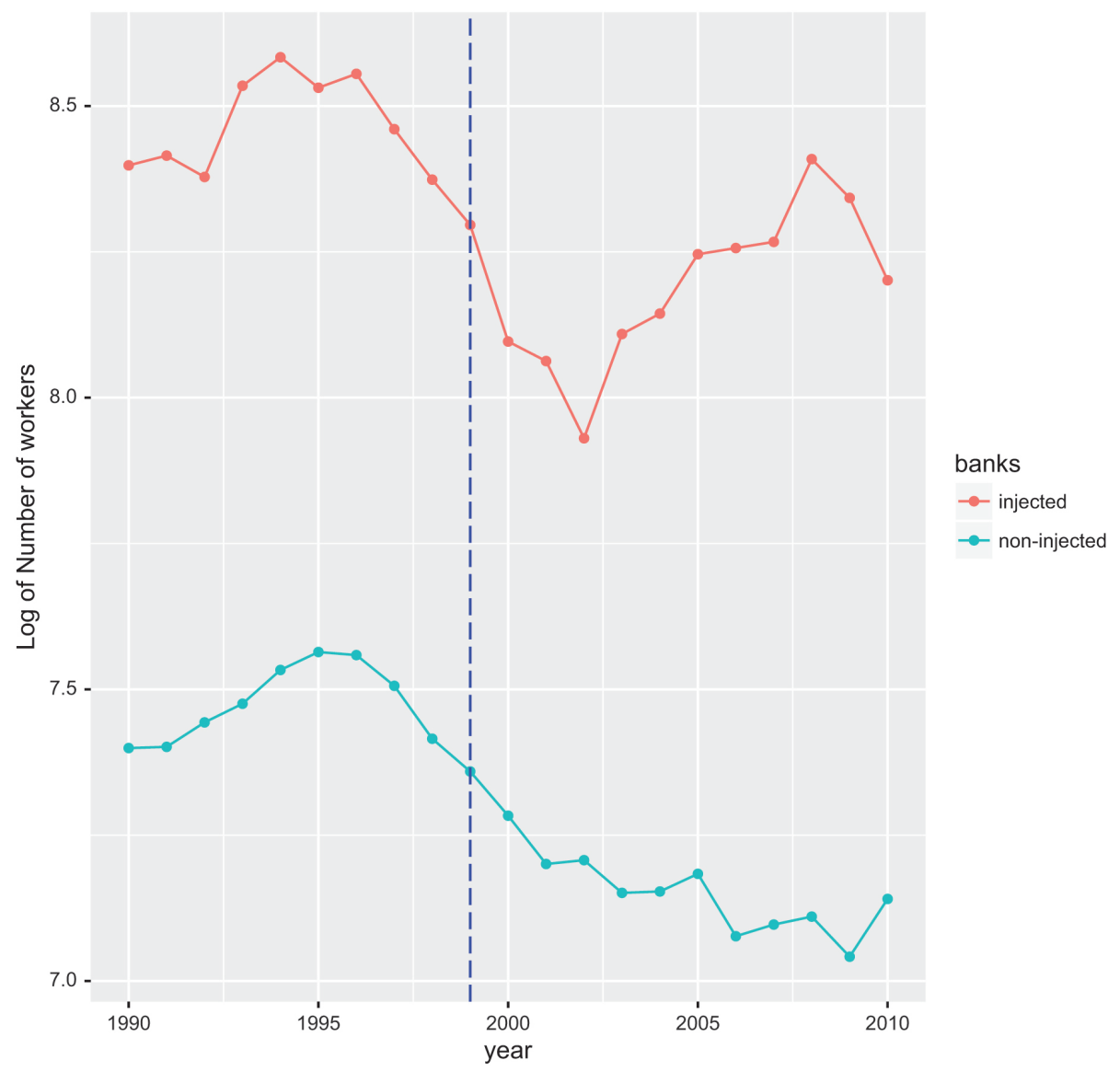

Figure 4: Examinations of pre-treatment trends: graphical analysis.

Source: Authors' own calculations. 


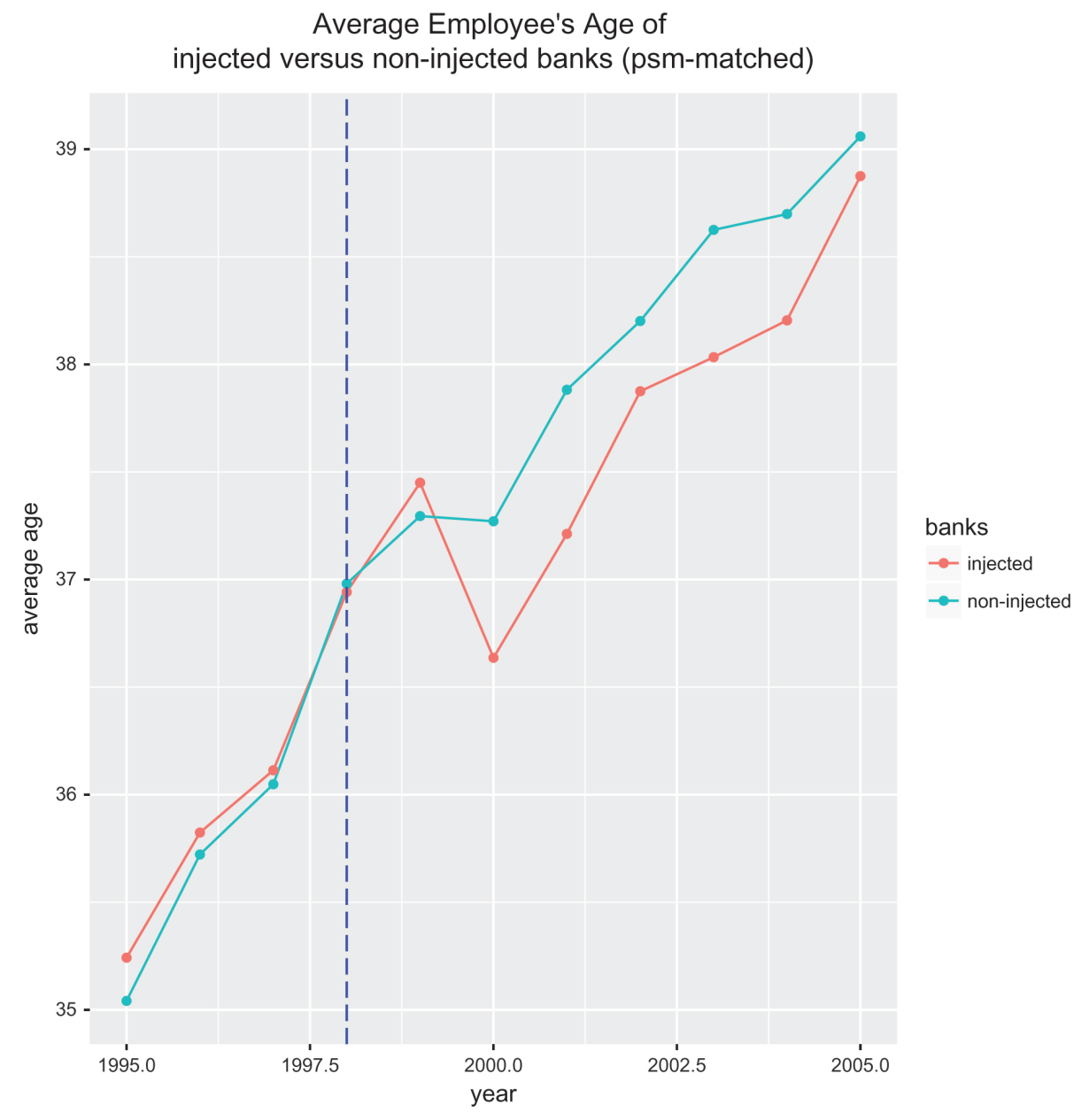

Figure 5: Examinations of pre-treatment trends: graphical analysis.

Source: Authors' own calculations. 
Number of workers of

injected versus non-injected banks, unconsolidated (psm-matched)

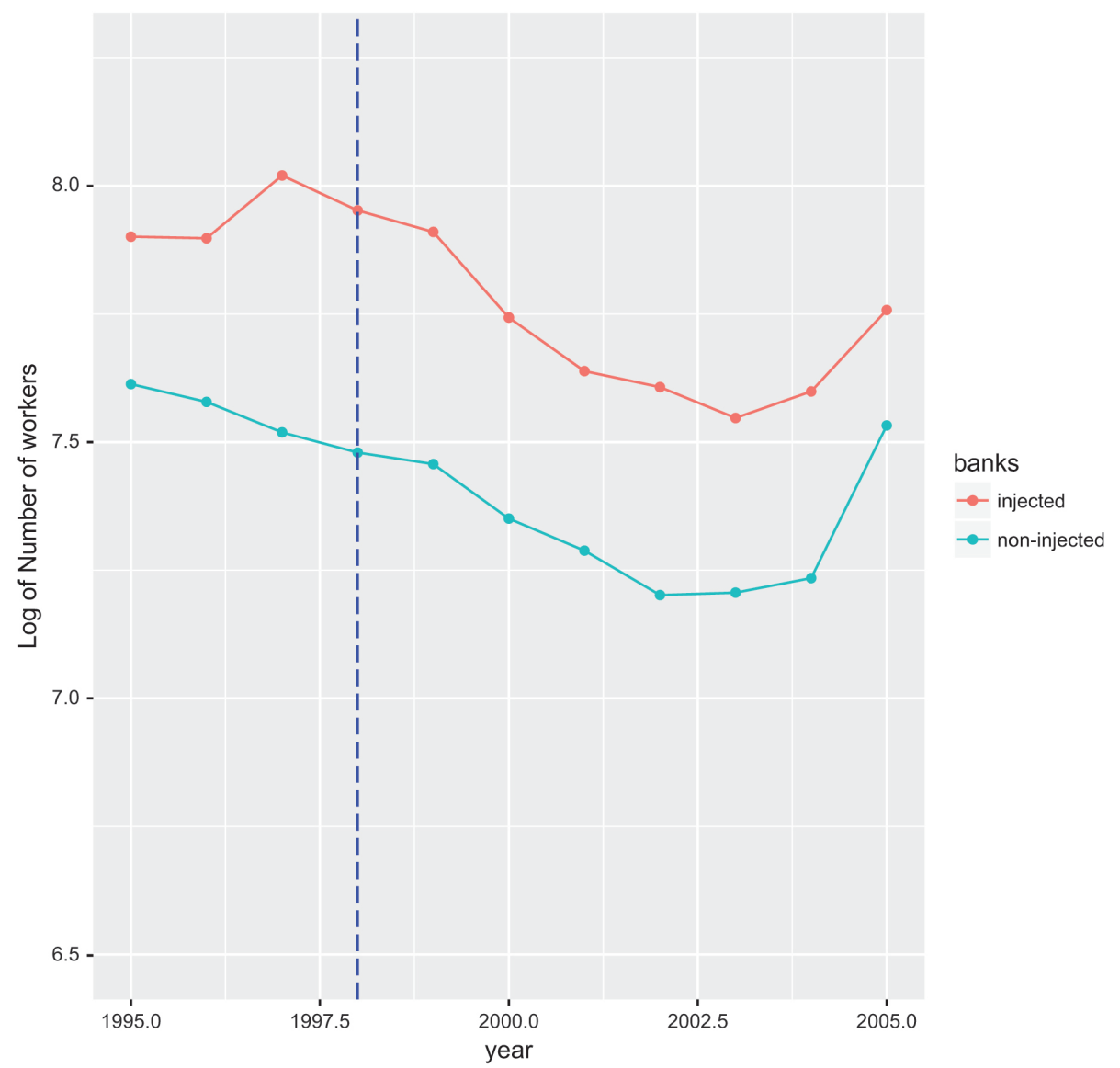

Figure 6: Examinations of pre-treatment trends: graphical analysis.

Source: Authors' own calculations.

Table 13: Examinations of pre-treatment trends: 1-year lead.

(4) (5) (6)

1 year lead

Lead

Employees $^{U N}$

Employees ${ }^{\mathrm{CON}}$

\section{Other covariates}

INJcross $_{t-0}$

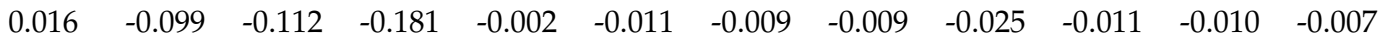
$\begin{array}{lllllllllllll}(0.127 & (0.226) & (0.229) & (0.221) & (0.008) & (0.013) & (0.013) & (0.014) & (0.047) & (0.027) & (0.027) & (0.028)\end{array}$

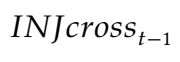

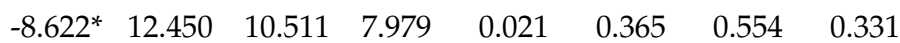

$\begin{array}{lllllll}(4.063) & (20.664)(20.418) & (20.546) & (0.346) & (0.793) & (0.800) & (0.847)\end{array}$

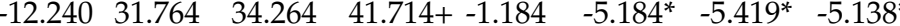

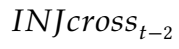
$\begin{array}{llllll}(9.416) & \text { (22.196) (22.259) (22.318) (0.942) (2.252) (2.325) } & \text { (2.449) }\end{array}$

INJcross $_{t-3}$ (10.523) (17.944) (16.955) (17.706) (0.384)

PAIDcross $_{t-0}$ $-21.556^{* *}-22.233^{* *}-25.171^{* *}-22.832^{* *}-1.956^{* *}-1.359^{* *}-1.199^{* *}-1.194^{* *}-1.311 \quad-0.543 \quad-0.430 \quad-0.467$ $\begin{array}{llllllllllll}(6.524) & (3.765) & (3.812) & (3.804) & (0.684) & (0.407) & (0.405) & (0.422) & (1.035) & (0.478) & (0.530) & (0.545)\end{array}$

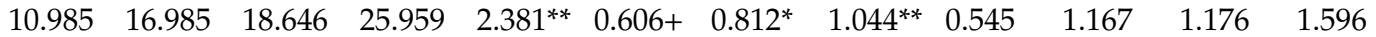

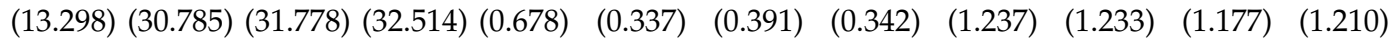

PAIDcross $_{t-1}$

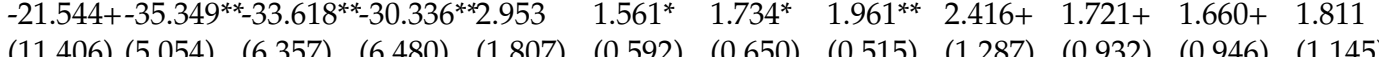

PAIDcross $_{t-2}$

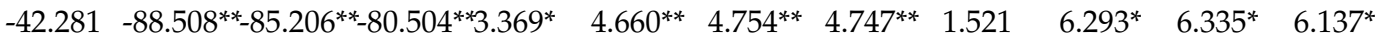
(28.425) (13.578) (13.887) (12.964) (1.685) (1.555) (1.505) (1.625) (1.194)

PAIDcross $_{t-3} \quad-21.623-47.651^{* *}-44.041^{* *}-36.489^{*} 2.769^{* *} 1.390^{* *} 1.566^{* *} 1.442^{*} 6.878+3.955^{* *} 4.120^{* *} 3.760^{* *}$

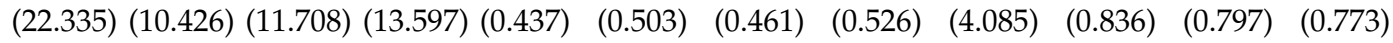

Lag of dep. var. $\begin{array}{llllllllllll}0.751^{* *} & 0.779^{* *} & 0.788^{* *} & 0.820^{* *} & 0.733^{* *} & 0.771^{* *} & 0.771^{* *} & 0.785^{* *} & 0.203 & 0.696^{* *} & 0.691^{* *} & 0.710^{* *}\end{array}$ $\begin{array}{lllllllllllll}0.032 & (0.034) & (0.035) & (0.039) & (0.038) & (0.034) & (0.037) & (0.045) & (0.152) & (0.032) & (0.033) & (0.031)\end{array}$ Salary

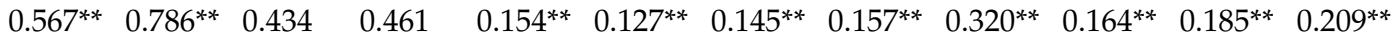




\begin{tabular}{|c|c|c|c|c|c|c|c|c|c|c|c|c|}
\hline & (0.192) & $(0.288)$ & (0.351) & (0.461) & (0.031) & (0.018) & $(0.021)$ & (0.034) & $(0.064)$ & (0.037) & (0.050) & (0.065) \\
\hline \multirow[t]{2}{*}{ Asset } & -0.261 & -0.056 & -0.216 & -0.249 & $0.076^{* *}$ & $0.052^{*}$ & $0.053^{*}$ & $0.050+$ & $0.345^{* *}$ & 0.084 & 0.086 & 0.083 \\
\hline & $(0.207)$ & $(0.271)$ & $(0.274)$ & $(0.270)$ & $(0.022)$ & $(0.022)$ & $(0.024)$ & $(0.027)$ & (0.103) & $(0.058)$ & $(0.063)$ & $(0.080)$ \\
\hline \multirow[t]{2}{*}{ Employees ${ }^{U N}$} & $-1.041^{* *}$ & $-1.512^{* *}$ & $-1.065+$ & -0.698 & $-0.007^{* *}$ & $-0.010^{* *}$ & $-0.008^{* *}$ & $-0.010^{* *}$ & $-0.015^{* *}$ & $-0.012^{* *}$ & $-0.011^{*}$ & $-0.015^{* *}$ \\
\hline & $(0.293)$ & $(0.515)$ & $(0.548)$ & (0.587) & $(0.001)$ & $(0.002)$ & $(0.002)$ & $(0.003)$ & $(0.005)$ & $(0.003)$ & $(0.004)$ & $(0.005)$ \\
\hline \multirow[t]{2}{*}{ Av. Age } & & & & & & & & & -0.002 & -0.000 & -0.000 & -0.003 \\
\hline & & & & & & & & & $(0.005)$ & $(0.004)$ & $(0.004)$ & (0.005) \\
\hline \multirow[t]{2}{*}{$R O A$} & 0.011 & 0.032 & $0.037+$ & 0.036 & $0.003^{* *}$ & $0.004^{* *}$ & $0.004^{* *}$ & $0.003^{* *}$ & 0.003 & -0.016 & -0.016 & -0.052 \\
\hline & (0.013) & $(0.020)$ & $(0.021)$ & (0.023) & (0.001) & $(0.001)$ & $(0.001)$ & $(0.001)$ & $(0.030)$ & $(0.027)$ & $(0.031)$ & $(0.043)$ \\
\hline \multirow[t]{2}{*}{ Job applicants } & $0.494^{*}$ & 0.424 & 0.495 & 0.328 & -0.003 & 0.000 & 0.004 & 0.014 & & & & \\
\hline & $(0.212)$ & $(0.325)$ & $(0.402)$ & $(0.489)$ & $(0.011)$ & $(0.016)$ & $(0.020)$ & $(0.023)$ & & & & \\
\hline \multirow[t]{2}{*}{ Nominal wage } & -0.113 & -0.344 & -0.358 & -0.017 & 0.001 & -0.017 & -0.007 & 0.052 & 0.023 & $-0.111+$ & $-0.126+$ & -0.100 \\
\hline & $(0.294)$ & $(0.426)$ & $(0.544)$ & $(0.722)$ & $(0.022)$ & $(0.029)$ & $(0.042)$ & $(0.050)$ & $(0.047)$ & $(0.056)$ & $(0.073)$ & $(0.091)$ \\
\hline \multirow[t]{2}{*}{ Constant } & $10.708^{*}$ & $10.769+$ & $11.996+$ & 7.856 & -0.249 & 0.217 & -0.156 & -0.770 & -1.636 & 0.815 & 0.633 & 0.734 \\
\hline & $(4.548)$ & $(5.544)$ & $(6.472)$ & (7.066) & $(0.375)$ & $(0.414)$ & $(0.523)$ & (0.636) & (1.627) & $(0.827)$ & $(0.833)$ & $(1.221)$ \\
\hline Observations & 2,352 & 903 & 713 & 529 & 2,352 & 903 & 713 & 529 & 1,107 & 450 & 360 & 273 \\
\hline$R$-squared & 0.897 & 0.923 & 0.919 & 0.923 & 0.958 & 0.976 & 0.977 & 0.976 & 0.672 & 0.799 & 0.792 & 0.761 \\
\hline \multirow{2}{*}{$\begin{array}{l}\text { Number of } \\
\text { banks }\end{array}$} & 172 & 50 & 40 & 30 & 172 & 50 & 40 & 30 & 147 & 49 & 40 & 30 \\
\hline & $\begin{array}{l}\text { (Full } \\
\text { sam- } \\
\text { ple) }\end{array}$ & (PSM) & (PSM) & (PSM) & $\begin{array}{l}\text { (Full } \\
\text { sam- } \\
\text { ple) }\end{array}$ & (PSM) & (PSM) & (PSM) & $\begin{array}{l}\text { (Full } \\
\text { sam- } \\
\text { ple) }\end{array}$ & (PSM) & (PSM) & (PSM) \\
\hline
\end{tabular}

Note: Estimation results of eqs (4), (5), and (6) that test for the existence of different pre-treatment trends between injected and non-injected banks. The first column of each Model is for full sample. The second, third, and fourth columns are for the PSM sample with the sample size 50, 40, and 30 , respectively. Robust standard errors in parentheses are clustered at the bank level.

*** $p<0.01$

${ }^{*} p<0.05$

$+p<0.1$.

Table 14: Examinations of pre-treatment trends: leads and lags.

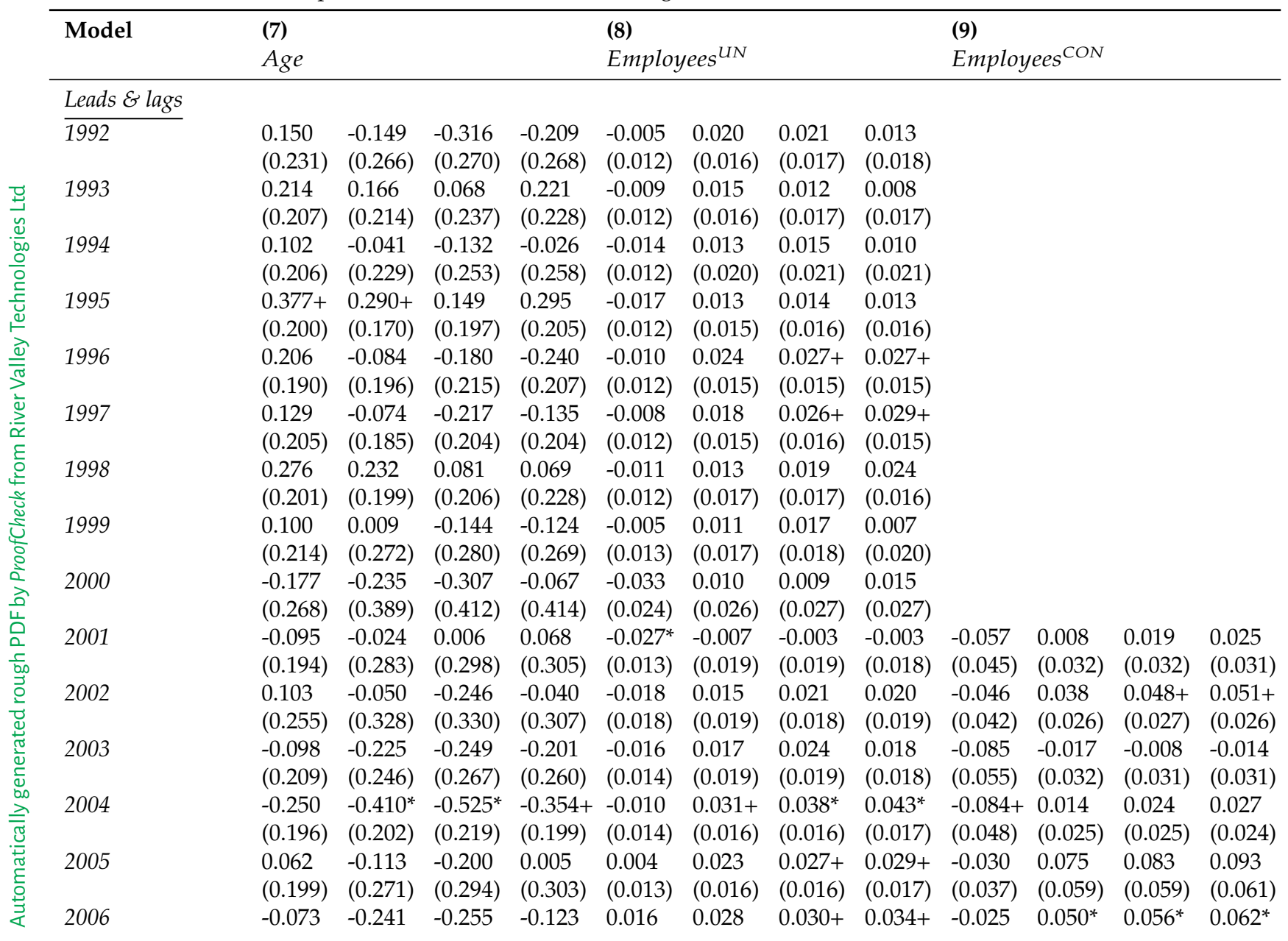




\begin{tabular}{|c|c|c|c|c|c|c|c|c|c|c|c|c|}
\hline & $(0.236)$ & (0.337) & (0.352) & (0.343) & (0.011) & (0.017) & (0.017) & (0.019) & (0.030) & $(0.021)$ & (0.021) & $(0.024)$ \\
\hline \multirow[t]{2}{*}{2007} & -0.282 & $-0.655+$ & $-0.680+$ & -0.450 & $0.030^{*}$ & $0.051^{*}$ & $0.048^{*}$ & $0.047+$ & -0.027 & $0.034^{*}$ & $0.041^{*}$ & $0.041+$ \\
\hline & $(0.237)$ & $(0.337)$ & $(0.352)$ & $(0.348)$ & $(0.012)$ & $(0.021)$ & $(0.021)$ & $(0.024)$ & $(0.030)$ & $(0.017)$ & $(0.017)$ & $(0.021)$ \\
\hline \multirow[t]{2}{*}{2008} & 0.133 & 0.172 & 0.140 & 0.396 & 0.011 & 0.017 & 0.021 & 0.021 & -0.038 & -0.007 & 0.003 & 0.009 \\
\hline & $(0.178)$ & $(0.216)$ & $(0.249)$ & $(0.266)$ & $(0.011)$ & $(0.014)$ & $(0.014)$ & $(0.014)$ & $(0.029)$ & $(0.024)$ & $(0.024)$ & $(0.027)$ \\
\hline \multirow[t]{2}{*}{2009} & 0.199 & 0.289 & 0.208 & 0.417 & -0.001 & -0.002 & -0.003 & -0.003 & -0.047 & 0.014 & 0.019 & 0.024 \\
\hline & $(0.212)$ & $(0.246)$ & $(0.265)$ & $(0.283)$ & $(0.010)$ & $(0.013)$ & $(0.013)$ & $(0.015)$ & $(0.029)$ & $(0.036)$ & $(0.036)$ & $(0.037)$ \\
\hline Other covariates & Yes & Yes & Yes & Yes & Yes & Yes & Yes & Yes & Yes & Yes & Yes & Yes \\
\hline Fixed effects & Yes & Yes & Yes & Yes & Yes & Yes & Yes & Yes & Yes & Yes & Yes & Yes \\
\hline Observations & 2,352 & 903 & 713 & 529 & 2,352 & 903 & 713 & 529 & 1,107 & 450 & 360 & 273 \\
\hline$R$-squared & 0.897 & 0.923 & 0.918 & 0.921 & 0.957 & 0.975 & 0.976 & 0.975 & 0.674 & 0.804 & 0.798 & 0.768 \\
\hline \multirow{2}{*}{$\begin{array}{l}\text { Number of } \\
\text { banks }\end{array}$} & 172 & 50 & 40 & 30 & 172 & 50 & 40 & 30 & 147 & 49 & 40 & 30 \\
\hline & $\begin{array}{l}\text { (Full } \\
\text { sam- } \\
\text { ple) }\end{array}$ & (PSM) & (PSM) & (PSM) & $\begin{array}{l}\text { (Full } \\
\text { sam- } \\
\text { ple) }\end{array}$ & (PSM) & (PSM) & (PSM) & $\begin{array}{l}\text { (Full } \\
\text { sam- } \\
\text { ple) }\end{array}$ & (PSM) & (PSM) & (PSM) \\
\hline
\end{tabular}

Note: Estimation results of eqs (7), (8), and (9) that test for the existence of different pre-treatment trends between injected and non-injected banks. Following Autor (2003), or "leads-and-lags" models, these models include the interaction terms between year dummies and a dummy for banks which receive injection in differences-in-differences model. The first column of each Model is for full sample. The second, third, and fourth columns are for the PSM sample with the sample size 50,40, and 30, respectively. Robust standard errors in parentheses are clustered at the bank level.

*** $p<0.01$

$* p<0.05$,

$+p<0.1$.

\section{Notes}

${ }^{1}$ They offered a nuanced interpretation on the shuffling behavior, observing that the decision of the bank management may not be malicious in that, in addition to the downsizing target, banks operated in an environment where they faced restrictions on layoffs owing to the existing labor law and the lifetime employment practice.

${ }^{2}$ Onji, Vera, and Corbett (2012) speculate that banks shuffled older workers, who were nearing retirement age, to subsidiaries, referring to Kato (2001) fieldwork on manufacturing firms to support their conjecture about bank behavior. However, they do not provide direct evidence.

${ }^{3}$ Under LTE, a regular employee works with a company until his/her retirement. Koike (1996) documents notably long tenures in the Japanese banking sector in the 1970s, compared with white-collar workers in manufacturing, wholesale, and retail, as well as with bankers in West Germany.

${ }^{4}$ Our primary contribution relative to Onji, Vera, and Corbett (2012) is in presenting direct evidence on the demographic shift. The evidence indicating that the average age did not increase after repayment discounts the possibility that workers shifted to subsidiaries were taken back by parent banks, once these banks were off the restructuring program. We would have observed a compensating increase otherwise. In addition, we employ longer time-series data, allowing us to evaluate the effects of repayments more thoroughly. Furthermore, we employ a higher frequency data.

${ }^{5}$ The past reports for individual cases are reported in http://www.meti.go.jp/sankatsuhou/nintei/past_result.html (accessed January $25,2013)$.

${ }^{6}$ We adjusted the original NEEDS data on age. For example, if the average age was 40 years and 11 months, NEEDS records the data as "40.11." However, our modified data records it as "40.92" (= $40+11 / 12)$.

${ }^{7}$ The data source for wage is the Basic Survey on Wage published by the Ministry of Health, Labor, and Welfare (MoHLW). The information on the number of job seekers is obtained from "Employment Referrals Statistics" reported in Labor Market Annals, also published by the MoHLW.

${ }^{8}$ We have tried lagging this variable to allow for potential endogeneity of ROA and including a lag of ROA along with its contemporaneous variable. The result was robust to these alternative specifications.

${ }^{9}$ Except for ROA, the other control variables are logarithmic values.

${ }^{10}$ Table 1 in Judson and Owen (1999) shows that, for $T=20$, the estimated bias on the coefficient on a covariate under the LSDV model is $0.009(0.006)$ with a standard error of $0.017(0.028)$ for the true coefficient of $0.2(0.8)$. The bias is $4.5 \%$ of the true coefficient and is not statistically significant. At this time dimension size, Judson and Owen (1999) caution that the coefficient on a lagged dependent variable may suffer from bias.

${ }^{11}$ The analysis in Table 5 employs a shorter time series than that in Table 4 . Therefore, the imprecise estimate in Table 5 may be due to weak power of the test: non-reporting of consolidated financial statement until 1999 and $T=10$ rather than 20 , in the analysis on the consolidated employment. As a robustness check, we re-estimated model (2) using the FY1999-FY2010 data, dropping the first two injection variables. We still found significantly negative coefficients so that the result is robust to this time-series length.

${ }^{12}$ Though the dependent variable in eq. (3) is on a consolidated basis, control variables for bank-specific effects are on an unconsolidated basis. As a robustness check, we re-estimated the model (3) using consolidated data instead. Again, there is almost no significant effect of injections, but the coefficients on lagged repayments are significantly positive.

${ }^{13}$ The system GMM version of model (1) includes as standard instruments: time effects, $\log$ of salaries, $\log$ of assets, $\log$ of job applicants, and log of wage. It includes the following variables in the GMM vector: lag of age, capital injections, and repayments. Three lags are used to instrument for the GMM variables. This equation was estimated in levels and was clustered at the bank level. The lagged variable of ROA was also included as an additional control. The system GMM version of model (2) includes time effects, $\log$ of salaries, log of assets, log of job applicants, log of wage, average age, capital injections, and repayments as standard instruments. It includes lagged employees 
(unconsolidated) as the only variable in the GMM vector. Five lags are used to instrument for the GMM variable. This equation was estimated in difference, using the two-step procedure and clustered at the bank level. The system GMM version of model (3) includes time effects, capital injections, and repayments as standard instruments. The vector of GMM variables includes lagged employees (consolidated), $\log$ of salaries, log of assets, log of job applicants, log of wage, average age, and lagged ROA (for the bank group). Two lags are used to instrument for the GMM variables. This equation was estimated in difference, using the two-step procedure and clustered at the bank level.

${ }^{14}$ We used alternative years for both pre- and post-injection periods and obtained equivalent results.

${ }^{15}$ The mean differences of average employee age of injected and non-injected banks is -1.2 in the post-injection period. A $t$-test indicates that this difference is statistically significant. This estimate is highly consistent with our initial regression analysis.

${ }^{16}$ To check the robustness of results, we estimate the main models with sample sizes of 30 and 50 . We obtain similar results for all samples.

${ }^{17}$ Some financial institutions may not have comparable counterparts. For example, the Bank of Yokohama is a regional bank, but is unique among regional banks in extending its branch network outside the locality. The bank would therefore not have a directly comparable counterpart among a group of regional banks, but would look much different from large city banks. As an additional check, we exclude Bank of Yokohama from our sample, and find the results to be quantitatively similar to the baseline results.

${ }^{18}$ As suggested by the referee, we estimated the Rosenbaum's bound using the rbound command in R.

${ }^{19}$ The pre-treatment trend graphs in the case of the matched sample includes 26 banks, 13 injected, and 13 non-injected.

\section{References}

Aakvik, Arild. 2001. “Bounding a Matching Estimator: The Case of a Norwegian Training Program." Oxford Bulletin of Economics and Statistics 63 (1): 115-143.

Adrian, Tobias, and Hyun-Song Shin. 2009. “Money, Liquidity, and Monetary Policy.” The American Economic Review 99 (2): 600-605.

Autor, David H. 2003. "Outsourcing at Will: The Contribution of Unjust Dismissal Doctrine to the Growth of Employment Outsourcing." Journal of Labor Economics 21 (1): 1-42.

Black, Lamont K., and Lieu N. Hazelwood. 2013. “The Effect of TARP on Bank Risk-Taking.” Journal of Financial Stability 9 (4): $790-803$.

Bresnahan, Timothy F., Erik Brynjolfsson, and Lorin M. Hitt. 2002. “Information Technology, Workplace Organization, and the Demand for Skilled Labor: Firm-Level Evidence." The Quarterly Journal of Economics 117 (1): 339-376.

Dehejia, Rajeev H., and Sadek Wahba. 1999. "Causal Effects in Nonexperimental Studies: Reevaluating the Evaluation of Training Programs." Journal of the American statistical Association 94 (448): 1053-1062.

Duchin, Ran, and Denis Sosyura. 2014. "Safer Ratios, Riskier Portfolios: Bank's Response to Covernment Aid." Journal of Financial Economics $113(1): 1-28$.

Flannery, Mark J., and Kristine Watson Hankins. 2013. “Estimating Dynamic Panel Models in Corporate Finance." Journal of Corporate Finance 19: 1-19.

Cenda, Yuji. 2003. “Who Really Lost Jobs in Japan? Youth Employment in an Aging Japanese Society.” In Labor Markets and Firm Benefit Policies in Japan and the United States., edited by Seiritsu Ogura, Toshiaki Tachibanaki, and David A. Wise, 103-134. Chicago: University of Chicago Press.

Cenda, Yuji, and Marcus E. Rebick. 2000. “Japanese Labour in the 1990s: Stability and Stagnation.” Oxford Review of Economic Policy 16 (2): 85-102.

Ciannetti, Mariassunta, and Andrei Simonov. 2013. “On the Real Effects of Bank Bailouts: Micro Evidence from Japan." American Economic Journal: Macroeconomics 5 (1): 135-167.

Hollander, Myles, and Douglas A. Wolfe. 1999. NonparametricStatistical Methods., 2nd. New York: John Wiley and Sons.

Hoshi, Takeo, and Anil K. Kashyap. 2005. "Solutions to Japan's Banking Problems: What Might Work and What Definitely will Fail." In Reviving Japan's Economy: Problems and Prescriptions., edited by T. Ito, H. Patrick, and D. Weinstein, 147-195. Cambridge: MIT Press.

Hoshi, Takeo, and Anil K. Kashyap. 2010. "Will the US Bank Recapitalization Succeed? Eight Lessons from Japan." Journal of Financial Economics 97 (3): 398-417.

Judson, Ruth A., and Ann L. Owen. 1999. “Estimating Dynamic Panel Data Models: A Guide for Macroeconomists." Economics Letters 65 (1): 9-15.

Kambayashi, Ryo, and Takao Kato. 2010. “The Japanese Employment System After the Bubble Burst: New Evidence.” In Japan's Bubble, Deflation, and Stagnation., edited by K. Hamada, A. Kashyap, and D. Weinstein, 217-262. Cambridge: MIT Press.

Kato, Takao. 2001. "The End of Lifetime Employment in Japan? Evidence from National Surveys and Field Research." Journal of the Japanese and International Economies 15 (4): 489-514.

Keele, Luke. 2010. ““An Overview of Rbounds: An R Package for Rosenbaum Bounds Sensitivity Analysis with Matched Data” White Paper. Columbus OH." $1-15$.

Koike, Kazuo. 1996. The Economics of Work in Japan. LTCB International Library Selection. Vol. 3. Tokyo: LTCB International Library Foundation.

OECD. OECD Employment Outlook Organization for Economic Cooperation and Development, 1999 Paris.

Onji, Kazuki, David Vera, and Jenny Corbett. 2012. "Capital Injection, Restructuring Targets and Personnel Management: The Case of Japanese Regional Banks." Journal of the Japanese and International Economies 26 (4): 495-517.

Roodman, David. 2009. “A Note on the Theme of Too Many Instruments." Oxford Bulletin of Economics and Statistics 71 (1): $135-158$.

Rosenbaum, Paul R. 2002. Observational Studies., 2nd. New York: Springer.

Rubin, Donald B., and Neal Thomas. 2000. “Combining Propensity Score Matching with Additional Adjustments for Prognostic Covariates." Journal of the American Statistical Association 95 (450): 573-585. 